\title{
Ghrelin Selectively Inhibits Cav3.3 Subtype of Low-Voltage-Gated Calcium Channels
}

\author{
Emilio Román Mustafá ${ }^{1}$ (D) Santiago Cordisco Gonzalez ${ }^{1} \cdot$ Jesica Raingo $^{1}$ (D) \\ Received: 29 March 2019 / Accepted: 16 August 2019 / Published online: 29 August 2019 \\ (C) Springer Science+Business Media, LLC, part of Springer Nature 2019
}

\begin{abstract}
The mechanisms by which ghrelin controls electrical activity in the hypothalamus are not fully understood. One unexplored target of ghrelin is $\mathrm{Ca}_{\mathrm{V}} 3$, responsible for transient calcium currents (T-currents) that control neuronal firing. We investigated the effect of ghrelin on $\mathrm{Ca}_{\mathrm{v}} 3$ subtypes and how this modulation impacts on neuronal activity. We performed whole-cell patch-clamp recordings in primary mouse hypothalamic cultures to explore the effect of ghrelin on T-currents. We also recorded calcium currents from transiently transfected tsA201 cells to study the sensitivity of each $\mathrm{Ca}_{\mathrm{V}} 3$ subtype to GHSR activation. Finally, we ran a computational model combining the well-known reduction of potassium current by ghrelin with the $\mathrm{Ca}_{\mathrm{V}} 3$ biophysical parameter modifications induced by ghrelin to predict the impact on neuronal electrical behavior. We found that ghrelin inhibits native $\mathrm{NiCl}_{2}$ sensitive current currents in hypothalamic neurons. We determined that $\mathrm{Ca}_{\mathrm{v}} 3.3$ is the only $\mathrm{Ca}_{\mathrm{v}} 3$ subtype sensitive to ghrelin. The modulation of $\mathrm{Ca}_{\mathrm{v}} 3.3$ by ghrelin comprises a reduction in maximum conductance, a shift to hyperpolarized voltages of the $I-V$ and steady-state inactivation curves, and an acceleration of activation and inactivation kinetics. Our model-based prediction indicates that the inhibition of $\mathrm{Ca}_{\mathrm{v}} 3.3$ would attenuate the stimulation of firing originating from the inhibition of potassium currents by ghrelin. In summary, we discovered a new target of ghrelin in neurons: the $\mathrm{Ca}_{\mathrm{v}} 3.3$. This mechanism would imply a negative feed-forward regulation of the neuronal activation exerted by ghrelin. Our work expands the knowledge of the wide range of actions of GHSR, a receptor potentially targeted by therapeutics for several diseases.
\end{abstract}

Keywords Ghrelin $\cdot$ GHSR $\cdot$ Ca $_{\mathrm{V}} 3.3 \cdot$ Excitability $\cdot$ Hypothalamus

$\begin{array}{ll}\text { Abbreviations } \\ \text { GHSR } & \text { Growth hormone secretagogue receptor } \\ \text { LEAP2 } & \text { Liver-expressed antimicrobial peptide 2 } \\ \text { KV } & \text { Voltage-gated potassium channels } \\ \mathrm{Ca}_{\mathrm{v}} 3 & \text { Low-voltage-gated calcium channels } \\ \text { DMEM } & \text { Dulbecco's modified Eagle's medium } \\ \text { FBS } & \text { Fetal bovine serum } \\ \text { eGFP } & \text { Enhanced green fluorescent protein } \\ I_{\text {peak }} & \text { Current peak } \\ \mathrm{G}_{\mathrm{q}} \text { DN } & \mathrm{G}_{\mathrm{q}} \text { dominant-negative mutant } \\ \text { RGS2 } & \text { Regulator of G protein signaling 2 } \\ \text { M a s - } & \text { Myristoylated C-terminal } \mathrm{G}_{\beta \gamma} \text {-binding domain } \\ \text { GRK2ct } & \text { of the G protein-coupled receptor kinase 2 }\end{array}$

Jesica Raingo

jraingo@gmail.com

1 Electrophysiology Laboratory of the Multidisciplinary Institute of Cell Biology (Argentine Research Council (CONICET)), Scientific Research Commission of the Province of Buenos Aires (CIC-PBA) and National University of La Plata (UNLP), Calle $526 \mathrm{~S} / \mathrm{N}$ entre 10 y 11, 1900 La Plata, Buenos Aires, Argentina

$\begin{array}{ll}I-V & \text { Current-voltage } \\ V_{1 / 2} & \text { Half activation voltage } \\ V_{\text {rev }} & \text { Reversal potential } \\ K & \text { Slope of activation } \\ G_{\max } & \text { Maximum conductance } \\ N & \text { Number of channels available to be open } \\ g & \text { Single channel conductance } \\ P_{\mathrm{o}} & \text { open probability }\end{array}$

\section{Introduction}

Ghrelin is a gut-produced peptide hormone with central effects including the control of appetite, reward, and memory processes [1-3]. Understanding the molecular mechanisms underlying its physiological effects would therefore help to utilize its receptor, GHSR (growth hormone secretagogue receptor), as a pharmacological target. The recent discovery of a novel endogenous liver-expressed antimicrobial peptide 2 (LEAP2) that could act as a natural antagonist of GHSR increases the spectrum of GHSR activity $[4,5]$. At the cellular 
level, ghrelin enhances gene expression [6-8]. More recently, it has been described that ghrelin also has a potent stimulatory effect on electrical activity $[9,10]$. In this regard, it is well known that ghrelin-mediated GHSR activation depolarizes neurons by inhibiting voltage-gated potassium channels $\left(\mathrm{K}_{\mathrm{V}} 7\right)$ via $\mathrm{G}_{\mathrm{q} / 11}$ [11]. Here, we aim to explore the impact of ghrelin on other channels that greatly contribute to excitability and firing in neurons: the low-voltage-gated calcium channels $\left(\mathrm{Ca}_{\mathrm{V}} 3\right)[12,13]$.

$\mathrm{Ca}_{\mathrm{V}} 3$ are also known as Transient channels (T-type calcium channels) due to their unique gating properties: fast activation and inactivation kinetics. $\mathrm{Ca}_{\mathrm{v}} 3$ calcium currents contribute to membrane potential changes such as calcium spikes that shape sodium-dependent burst firing [13-15], making them a great target for controlling electrical activity in neurons. Moreover, $\mathrm{Ca}_{\mathrm{V}} 3$ are responsible for calcium window currents in neurons due to the overlap between their voltage activation and inactivation curves $[13,16,17]$. Targeting $\mathrm{Ca}_{\mathrm{v}} 3$ also modulates calcium homeostasis in neurons [14] since $\mathrm{Ca}_{\mathrm{V}} 3$ participate in dendritic calcium spikes [18, 19], calcium-dependent intracellular synaptic release [20,21], and neuronal differentiation [22]. T-type calcium channels are encoded by three $\mathrm{Ca}_{\mathrm{V}}$ genes: CACNA1G, CACNA1H, and CACNA1I $\left(\mathrm{Ca}_{\mathrm{V}} 3.1\right.$, $\mathrm{Ca}_{\mathrm{V}} 3.2$, and $\mathrm{Ca}_{\mathrm{v}} 3.3$, respectively) [23-25]. Because subtype-specific blockers are not available [26, 27], the biophysical characterization of $\mathrm{Ca}_{\mathrm{v}} 3.1-3$ relies on the study of clones in a heterologous expression system. Such studies have revealed that $\mathrm{Ca}_{\mathrm{v}} 3.3$ has distinct properties including larger conductance, slower activation and inactivation, and faster deactivation kinetics than $\mathrm{Ca}_{\mathrm{v}} 3.1-2$ [13, 28-30]. Cav3.1-2 are widely distributed in many excitable tissues including brain and peripheral nervous tissue, cardiac, vascular and non-vascular smooth muscle, lung, endocrine, and sperm [31]. In contrast, $\mathrm{Ca}_{\mathrm{v}} 3.3$ is exclusively expressed in the brain $[25,31]$ including the hypothalamus, an area highly enriched in GHSR and accessible to circulating ghrelin [32].

All $\mathrm{Ca}_{\mathrm{V}} 3$ subtypes are regulated by intracellular signaling cascades, many of which arise from the activation of GPCRs by extracellular chemical signals $[14,31,33,34]$. In particular, we are interested in the ghrelin receptor pathways. GHSR displays two activity modes since it is capable of being activated by its natural agonist ghrelin but also displays constitutive activity [9]. The relative relevance of these two modes of activity in different brain areas could be related not only to the GHSR expression level but also to the amount of accessible ghrelin in those areas [35]. In this regard, we have recently shown that GHSR constitutive activity modulates GABA release at the hippocampus, a brain area with restricted access to ghrelin [36]. Moreover, we have also shown that $\mathrm{Ca}_{\mathrm{V}}$ channels are sensitive to GHSR constitutive activity only if $\mathrm{Ca}_{\mathrm{v}} \beta$ auxiliary subunit is present in the channel complex [37]. On the other hand, the hypothalamus and more specifically the arcuate nucleus are areas highly reachable by the circulating ghrelin that activates GHSR modulating food intake and energy expenditure [38-40]. Here, we explore a new target of ghrelin-evoked GHSR activity: the $\mathrm{Ca}_{\mathrm{V}} 3$ as a contribution to the electrical effect of ghrelin in hypothalamic neurons. We used whole-cell patch-clamp recordings in primary hypothalamic cultures and a heterologous expression system to explore the sensitivity of $\mathrm{Ca}_{\mathrm{V}} 3$ subtypes to GHSR activation by ghrelin, and we also used a computational model to predict the impact of our results on neuronal electrical behavior.

\section{Methods}

\section{Cell Culture and Transient Transfection}

tsA201 cells were grown in Dulbecco's modified Eagle's medium (DMEM; Gibco) with 10\% fetal bovine serum (FBS; Internegocios) and split when $80 \%$ confluence was achieved. Cells were transfected with plasmids containing voltage-gated calcium channel subunit $\mathrm{Ca}_{\mathrm{v}} 3.1$ (CACNA1G, GenBank accession no. AF190860) or $\mathrm{Ca}_{\mathrm{V}} 3.2-\mathrm{GFP}$ (CACNA1H, GenBank accession no. NM021098) or $\mathrm{Ca}_{\mathrm{V}} 3.3$ (CACNA1I, GenBank accession no. NM_021096), with or without GHSR (GHSR, GenBank accession no. AY429112). To identify transfected cells, eGFP (enhanced green fluorescent protein)containing plasmid was used. Transfections were done using Lipofectamine 2000 (Invitrogen) and Opti-MEM (Gibco). When needed, empty pcDNA3.1 (+) was co-transfected to maintain the same amount of DNA between conditions. To study GHSR signaling, plasmids containing the myristoylated C-terminal $\mathrm{G}_{\beta \gamma}$-binding domain of the $\mathrm{G}$ protein-coupled receptor kinase 2 (MAS-GRK2-ct) [41, 42] or a $\mathrm{G}_{\mathrm{q}}$ dominantnegative mutant $\left(\mathrm{G}_{\mathrm{q}-} \mathrm{Q} 209 \mathrm{~L} / \mathrm{D} 277 \mathrm{~N}\right)$, or a regulator of $\mathrm{G}$ protein signaling 2 (RGS2) were co-transfected.

Lipofectamine was used according to the manufacturer's specifications. Transfected cells were cultured for $48 \mathrm{~h}$ to allow $\mathrm{Ca}_{\mathrm{V}}$ expression. On the day of the experiment, cells were detached from the culture disk with $0.25 \mathrm{mg} / \mathrm{ml}$ trypsin (Microvet), then they were rinsed twice and kept at room temperature $\left(23^{\circ} \mathrm{C}\right)$ in DMEM.

$\mathrm{Ca}_{\mathrm{v}} 3.3$ clone was provided by Dr. D. Lipscombe (Brown University, Providence, RI). GHSR clone was provided by Dr. J. Marie (Université de Montpellier, Montpellier, France). $\mathrm{Ca}_{\mathrm{V}}$ 3.2-GFP clone was a gift from Dr. E. Bourinet (Institut de Génomique Fonctionnelle, Université de Montpellier, Montpellier, France).

\section{Drugs}

Ghrelin esterified with $n$-octanoic acid (Global Peptide, cata$\log$ no. PI-G-03) was used as GHSR agonist. 


\section{Animals}

C57BL/6 wild-type mice were housed in a $12 \mathrm{~h}$ light-dark cycle in a climate-controlled room $\left(22^{\circ} \mathrm{C}\right)$ at the IMBICE animal facility. Animals had ad libitum access to water and food. This study was performed in strict accordance with the recommendations of the Guide for the Care and Use of Laboratory Animals of the National Research Council. Animal suffering was minimized. All experimentation received approval from the Institutional Animal Care and Use Committee of the IMBICE.

\section{Neuronal Primary Culture}

Wild-type mice at embryonic days 15-17 were used. The protocol used was described in [43]. Embryos were quickly removed after pregnant mice dislocation. Embryo brains were placed on the dorsal face to remove the hypothalamus using forceps. Hypothalamus were placed in sterile Hank's solution and rinsed twice. Cell dissociation was done at $37{ }^{\circ} \mathrm{C}$ for $20 \mathrm{~min}$ with $0.25 \mathrm{mg} / \mathrm{ml}$ trypsin (Microvet). After that, $300 \mu \mathrm{FBS}$ was used to stop the enzyme digestion and $0.28 \mathrm{mg} / \mathrm{ml}$ deoxyribonuclease I from bovine pancreas (Sigma-Aldrich) was added. Cells were mechanically dissociated and plated (about 60,000 cells) on 12-mm-diameter glass coverslips treated previously with poly-L-lysine (SigmaAldrich) and laid over 24-well plates. Cells were placed at $37{ }^{\circ} \mathrm{C}$ in a $95 \%$ air and $5 \% \mathrm{CO}_{2}$ atmosphere with DMEM (Microvet)/F12 1:1 medium supplemented with B27 supplement (1:50; Gibco), 10\% FBS, $0.25 \%$ glucose, 2 mM glutamine (Gibco), $3.3 \mu \mathrm{g} / \mathrm{ml}$ insulin (Novo Nordisk Pharmaceutical Industries, Inc.), $40 \mu \mathrm{g} / \mathrm{ml}$ gentamicin sulfate salt (Richet), and $1 \%$ vitamin solution (Microvet). After 4 days in culture, half of the medium was replaced by fresh medium containing cytosine $\beta$-D-arabinofuranoside (Sigma-Aldrich) to reach a final concentration of $5 \mu \mathrm{M}$.

\section{Electrophysiology}

Axopatch 200 amplifier (Molecular Devices) was used for patch-clamp experiments, which were all in whole-cell and voltage-clamp configuration. Data were sampled at $20 \mathrm{kHz}$ and filtered at $10 \mathrm{kHz}(-3 \mathrm{~dB})$ using PCLAMP8.2 software (Molecular Devices). Recording pipettes with resistances between 2 and $4 \mathrm{M} \Omega$ were used and filled with internal solution. Series resistances of less than $6 \mathrm{M} \Omega$ were admitted and compensated $80 \%$ with a $10-\mu$ s lag time. We discarded cells with a leak current higher than $100 \mathrm{pA}$ at $-100 \mathrm{mV}$ and leak current was subtracted online using a $\mathrm{P} /-4$ protocol. We perfused solutions from a $10-\mathrm{ml}$ syringe containing bath solution placed $30 \mathrm{~cm}$ over the patch clamp chamber so the gravity drives the liquid to the chamber. The flow rate was regulated at $1 \mathrm{ml} / \mathrm{min}$ with a valve. The perfusion inlet attaches several three-way stopcocks for delivering different solutions to the chamber. Control, ghrelin, and nickel-containing solutions were applied with this system connected to different ports of the stopcocks. The liquid junction potential between the internal and the external solution containing $5 \mathrm{mM} \mathrm{CaCl}_{2}$ (see below) was $\sim 5.5 \mathrm{mV}$ and between the internal and the external solution containing $10 \mathrm{mM} \mathrm{BaCl}_{2}$ solution (see below) was $6.5 \mathrm{mV}$. These values were measured before experiments and non-corrected, thus all voltages showed were slightly more negative. All recordings were obtained at room temperature $\left(\sim 24^{\circ} \mathrm{C}\right)$. Internal pipette solution contained $(\mathrm{mM}) 134 \mathrm{CsCl}$, 10 EGTA, 1 EDTA, 10 HEPES, and $4 \operatorname{MgATP}$ (pH 7.2 with $\mathrm{CsOH})$.

- Barium currents of transiently transfected tsA201 cells: external solution contained (in $\mathrm{mM}$ ) $10 \mathrm{BaCl}_{2}, 1 \mathrm{MgCl}_{2}, 10$ HEPES, 140 TEA-chloride, and $6 \mathrm{CsCl}(\mathrm{pH} 7.4$ with $\mathrm{CsOH})$.

The test-pulse protocol consisted in square pulses applied from -100 to $-30 \mathrm{mV}$ for $\mathrm{Ca}_{\mathrm{V}} 3.1$ and $\mathrm{Ca}_{\mathrm{v}} 3.3$, and from 100 to $-20 \mathrm{mV}$ for $\mathrm{Ca}_{\mathrm{v}} 3.2$, for $200 \mathrm{~ms}$ every $10 \mathrm{~s}$.

- Calcium currents of primary neuronal cultures: 7-15day in vitro mouse-cultured neurons were patched at a holding potential of $-80 \mathrm{mV}$ by applying square test pulses to $20 \mathrm{mV}$ for $200 \mathrm{~ms}$ every $10 \mathrm{~s}$. Neurons were bathed with high sodium external solution containing $(\mathrm{mM}) 135 \mathrm{NaCl}, 4.7 \mathrm{KCl}$, $1.2 \mathrm{MgCl}_{2}, 2.5 \mathrm{CaCl}_{2}, 10$ HEPES, and 10 glucose (pH 7.4 with $\mathrm{NaOH}$ ). After getting the whole-cell configuration, $\mathrm{Ca}_{\mathrm{V}}$ currents were recorded by replacing the external solution with a high calcium solution containing $(\mathrm{mM}) 5 \mathrm{CaCl}_{2}, 135$ choline chloride, $1 \mathrm{MgCl}_{2}, 10$ HEPES, 10 glucose, and 0.001 tetrodotoxin (TTX; Sigma-Aldrich) (pH 7.4 with $\mathrm{CsOH}$ ). Ground electrode was placed in a separated compartment containing $2 \mathrm{M} \mathrm{KCl}$ connected with the recording chamber containing bath solution by a $2 \mathrm{M} \mathrm{KCl}$-agar salt bridge to avoid change on junction potentials due to bath exchange during recordings. We checked the absence of basal current run-down in two neurons during more than $100 \mathrm{~ms}$.

\section{Modeling}

Simulations of thalamic reticular neurons behavior were performed using the NEURON simulation environment [44]. We used the three-compartment model configuration of burst behavior described by [45] (accession no. 17663, available on Yale University (https://senselab.med.yale.edu/modeldb/)). The native T-current $\left(I_{\mathrm{T}}\right)$ in the model was replaced by the summation of $\mathrm{Ca}_{\mathrm{v}} 3.1, \mathrm{Ca}_{\mathrm{v}} 3.2$, and $\mathrm{Ca}_{\mathrm{v}} 3.3$ currents. The $\mathrm{Ca}_{\mathrm{V}} 3.3$ electrophysiological parameters for control and ghrelin conditions in the model - voltage-dependent time constants (activation and inactivation), the activation and inactivation parameters - were substituted by our experimental data while the $\mathrm{Ca}_{\mathrm{v}} 3.1$ and $\mathrm{Ca}_{\mathrm{v}} 3.2$ parameter values were extracted from a previous study [12]. The equations utilized are the following: Boltzmann equations for activation $\left(m_{\infty}\right)(1)$ and steady- 
state inactivation $\left(h_{\infty}\right)(2)$ curves and one phase decay exponential equations for the voltage dependency of the activation $\left(\mathrm{Tau}_{\mathrm{m}}\right)(3)$ and inactivation $\left(\mathrm{Tau}_{\mathrm{h}}\right)(4)$ time constants.

$$
\begin{aligned}
& m_{\infty}(V)=I_{0}+\left(I_{\max }-I_{0}\right) /\left(1+e^{\left(\left(V_{50}-V\right) / \text { slope }\right)}\right) \\
& h_{\infty}(V)=I_{0}+\left(I_{\max }-I_{0}\right) /\left(1+e^{\left(\left(V_{50}-V\right) / \text { slope }\right)}\right) \\
& \operatorname{Tau}_{m}(V)=\left(\operatorname{Tau}_{(0)}-\operatorname{Tau}_{(\infty)}\right) * e^{\left(-k^{*} V\right)}+\operatorname{Tau}_{(\infty)} \\
& \operatorname{Tau}_{h}(V)=\left(\operatorname{Tau}_{(0)}-\operatorname{Tau}_{(\infty)}\right) * e^{\left(-k^{*} V\right)}+\operatorname{Tau}_{(\infty)}
\end{aligned}
$$

To emulate our data, we reduced $40 \%$ by multiplying by 0.6 the fraction of $I_{\mathrm{T}}$ current corresponding to this $\mathrm{Ca}_{\mathrm{V}} 3$ subtype. In addition, to simulate the previous effect of ghrelin on potassium currents [11], we reduced $50 \%$ of this current in the condition in presence of ghrelin by multiplying by 0.5 the equation for this potassium conductance named as $I_{\mathrm{K}}$ in the model. Firing frequency and latency time were determined using PCLAMP10.7 software (Molecular Devices). The membrane potential was recorded from the virtual soma during $200 \mathrm{~ms}$ injecting $0.08 \mathrm{nA}$ of current. The modeling experiments were performed at $36^{\circ} \mathrm{C}$.

\section{Statistics}

Data were analyzed and visualized using the OriginPro 9 (Origin-Lab) and GraphPad Prism 6 (GraphPad Software, Inc.) software. We used Kolmogorov-Smirnov to test for conformity to a normal distribution, and variance homogeneity was examined using Bartlett's (normally distributed data) and Brown-Forsythe's (non-normally distributed data) test. $P$ values were calculated from one- or two-sample Student's $t$ tests (normally distributed data) or Mann-Whitney test (nonnormally distributed data), and multiple comparison one-way ANOVA with Tukey's post-test (normally distributed data). In the same experiments, we used paired sample Student's $t$ test to estimate $P$ values. We used extra-sum square $F$ test to compare different data function fits. The specific statistical test used is indicated for each data set. Data were expressed as mean \pm SEM.

\section{Results}

To explore the effect of ghrelin on native neuronal $\mathrm{Ca}_{\mathrm{V}} 3$ channels, we measured voltage-gated calcium currents in e15-17 hypothalamic neurons in culture stimulated with square depolarizing pulses from -80 to the potential expected for maximum $\mathrm{T} / \mathrm{Ca}_{\mathrm{v}} 3$ current activation in our experimental conditions: $-20 \mathrm{mV}$ [46]. In addition to the low-voltage maneuver, we also applied $50 \mu \mathrm{M}$ of $\mathrm{NiCl}_{2}$ that will block T- and Rtype calcium currents $[47,48]$. Thus, we tested the effect of ghrelin on these currents with or without $\mathrm{Ni}^{2+}[46,49]$ (Fig. 1a). We found that a saturating dose of $500 \mathrm{nM}$ ghrelin $[9,50]$ inhibits the currents and that pre-application of $\mathrm{Ni}^{2+}$ occludes this effect. Moreover, we observed that the percentage of current sensitive to $\mathrm{Ni}^{2+}$ is reduced by pre-application of ghrelin (Fig. 1b). This effect was completely washable in at least two neurons (data not shown). Moreover, we performed current-voltage $(I-V)$ curves in presence or not of ghrelin and found an inhibitory effect over a wide range of voltages (Fig. 2), in accordance with our previous data showing a inhibitory effect of ghrelin on high-voltage-activated (HVA) calcium currents [9]. Thus, we found that, beside the effect of ghrelin on HVA channels, native calcium currents evoked at $-20 \mathrm{mV}$ and sensitive to $\mathrm{Ni}^{2+}$ are also prone to ghrelinmediated inhibition.

Since our experiments in neurons suggested that Tcurrents could be inhibited by ghrelin and there are critical differences among the $\mathrm{Ca}_{\mathrm{V}} 3$ subtypes that contribute to these currents in neurons, we next investigated the effect of ghrelin on $\mathrm{Ca}_{\mathrm{V}} 3.1, \mathrm{Ca}_{\mathrm{V}} 3.2$, and $\mathrm{Ca}_{\mathrm{V}} 3.3$ isolated currents in a heterologous expression system. In order to do this, we co-expressed human $\mathrm{Ca}_{\mathrm{V}} 3$ clones together with GHSR in tsA201 cells and evaluated the effect of $500 \mathrm{nM}$ ghrelin on $\mathrm{Ca}_{\mathrm{V}} 3$ currents. We found that only $\mathrm{Ca}_{\mathrm{V}} 3.3$ was sensitive to ghrelin, while $\mathrm{Ca}_{\mathrm{V}} 3.1$ and $\mathrm{Ca}_{\mathrm{v}} 3.2$ remained unaffected. The effect of ghrelin on $\mathrm{Ca}_{\mathrm{V}} 3.3$ current was fully washable at least in two cells (data not shown). Figure 3 displays representative traces and time courses of this experiment as well as the average percentage of peak current inhibition for the three $\mathrm{Ca}_{\mathrm{V}} 3$ subtypes. In order to exclude the possibility of a GHSRindependent effect of ghrelin on $\mathrm{Ca}_{\mathrm{V}} 3.3$, we assayed the effect of ghrelin on tsA201 cells transfected only with $\mathrm{Ca}_{\mathrm{v}} 3.3$ (without GHSR), and we failed to find an effect ( $I_{\text {peak }}$ inhibition by ghrelin $=3.3 \pm 2.0 \%, P=0.1953$, test value $=0$, one-sample Student's $t$ test). We also performed a dose-response curve for the inhibitory effect of ghrelin on $\mathrm{Ca}_{\mathrm{v}} 3.3$ current and found an $\mathrm{EC}_{50}$ value of $346.1 \pm$ $1.2 \mathrm{nM}$ and a maximum inhibition of $32.5 \pm 3.9 \%$ (Fig. 4), indicating a concentration-dependent effect of ghrelin on $\mathrm{Ca}_{\mathrm{V}}$ 3.3. Our results suggest that the ghrelin effect on $\mathrm{Ca}_{\mathrm{v}} 3$ currents is subtype specific for $\mathrm{Ca}_{\mathrm{v}} 3.3$.

We also investigated which signaling cascade is implicated in the effect of ghrelin on $\mathrm{Ca}_{\mathrm{v}}$ 3.3. Since GHSR is mainly coupled to $G_{\mathrm{q}}$, we assayed the effect of ghrelin under two different conditions where $G_{q}$ activity is inhibited: in tsA201 cells co-expressing a $\mathrm{G}_{\mathrm{q}}$-dominant negative peptide $\left(\mathrm{G}_{\mathrm{q}} \mathrm{DN}\right)$ and $\mathrm{G}_{\mathrm{q}}$ and $\mathrm{G}_{\mathrm{s}}$ antagonist peptide (RGS2) [51-53]. We also explored the participation of $\mathrm{G}_{\beta \gamma}$ by incorporating a $\mathrm{G}_{\beta \gamma}$ buffer peptide (Mas-GRK2-ct) [41, 42]. As we show in Fig. 5, the inhibitory effect of ghrelin was occluded when $\mathrm{G}_{\mathrm{q}}$ was unable to activate its signaling cascades, while $\mathrm{G}_{\beta \gamma}$ is not required for the effect. 

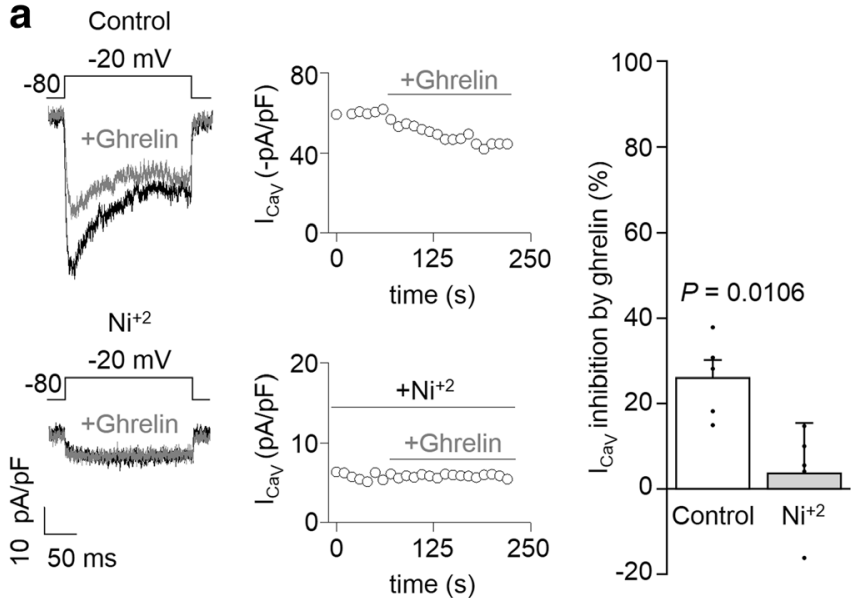

Fig. 1 Ghrelin inhibits $\mathrm{NiCl}_{2}$ sensitive currents in hypothalamic cultured neurons. a Representative calcium current $\left(I_{\mathrm{CaV}}\right)$ traces and time course from cultured neurons evoked at $-20 \mathrm{mV}$ from a holding potential of $80 \mathrm{mV}$ for $200 \mathrm{~ms}$ in control conditions (Control) and in presence of $50 \mu \mathrm{M} \mathrm{NiCl} 2\left(\mathrm{Ni}^{+2}\right)$, before and after application of $500 \mathrm{nM}$ ghrelin and averaged percentage of $I_{\mathrm{CaV}}$ inhibition by ghrelin ( $n=5$ in each condition). Dots represent the inhibition calculated for individual neuron. b

We next studied the biophysical parameters that contribute to the ghrelin-mediated inhibition of $\mathrm{Ca}_{\mathrm{V}} 3.3$ current in tsA201 cells co-expressing $\mathrm{Ca}_{\mathrm{V}} 3.3$ and GHSR. We generated currentvoltage $(I-V)$ curves in the presence or absence of ghrelin and found that $\mathrm{Ca}_{\mathrm{v}} 3.3$ current was significantly inhibited by ghrelin at a wide range of voltages ( -30 to $20 \mathrm{mV}$ ) (Fig. 6a). We also compared the fit parameters of the $I-V$ curves and observed that ghrelin causes a small but significant left shift in the activation. This is reflected in the normalized $I-V$ curves (Fig. 5a) and in a statistical difference in the half activation voltage $\left(V_{1 / 2}\right)$, without changes in reversal potential $\left(V_{\text {rev }}\right)$ or

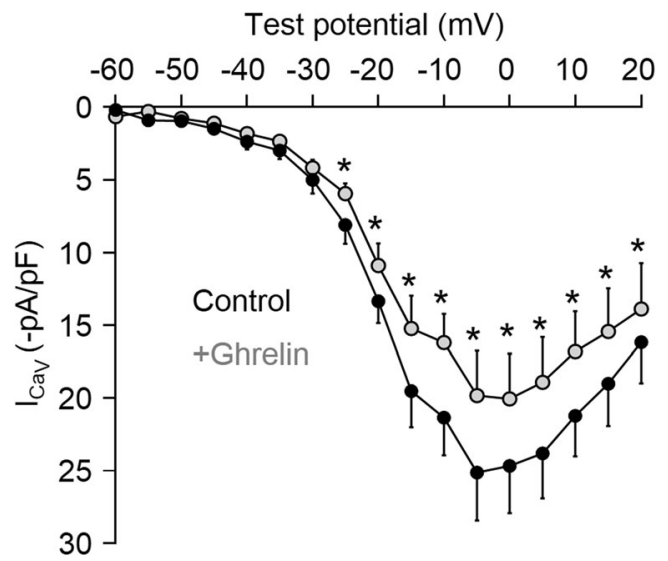

Fig. 2 Ghrelin inhibits calcium currents in hypothalamic cultured neurons in a range of membrane voltages. Averaged calcium current peak-voltage $(I-V)$ relationship from cultured neurons in control conditions (Control) and in presence of $500 \mathrm{nM}$ ghrelin (+Ghrelin). Stars represent statistical differences with $P<0.05(n=11)$. Paired sample Student's $t$ test

\section{b}
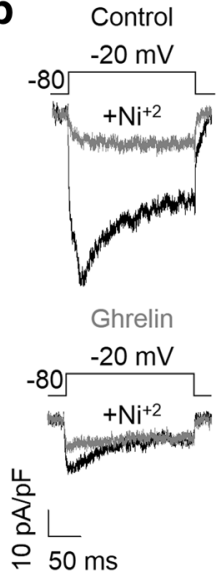
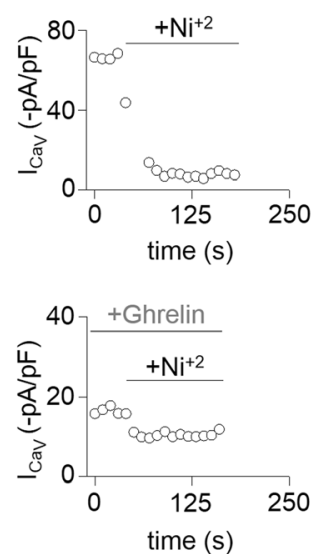

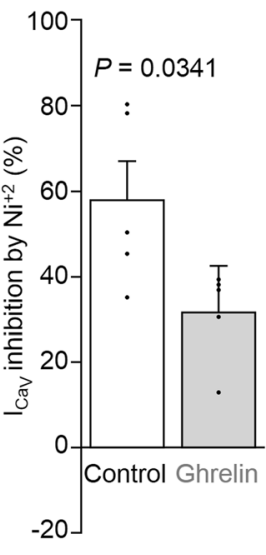

Representative calcium current $\left(I_{\mathrm{CaV}}\right)$ traces and time course from cultured neurons evoked at $-20 \mathrm{mV}$ from a holding potential of $-80 \mathrm{mV}$ for $200 \mathrm{~ms}$ in control conditions (Control) and in presence of $500 \mathrm{nM}$ ghrelin (Ghrelin), before and after the application of $50 \mu \mathrm{M} \mathrm{NiCl}_{2}$ and averaged percentage of $\mathrm{I}_{\mathrm{CaV}}$ inhibition by $\mathrm{Ni}^{+2}$ ( $n=5$ in each condition). Dots represent the inhibition calculated for individual neuron. One-sample Student's $t$ test

the slope of activation $(K)$ (Fig. 6b). In addition, we found that ghrelin reduces the maximum conductance $\left(G_{\max }\right)$ value by about $40 \%$ (Fig. 5 b). This reduction in $G_{\max }$ could be due to changes in the number of channels available to be open $(N)$, the single channel conductance $(g)$, and/or open probability $\left(P_{\mathrm{o}}\right)$. In order to assay whether ghrelin affects $\mathrm{Ca}_{\mathrm{V}} 3.3$ open probability, we performed an instant $I-V$ curve protocol using a depolarizing pre-pulse to $+60 \mathrm{mV}$ (Fig. 6c). We then divided the $I-V$ curve by the instant $I-V$ curve for each cell in the presence or absence of ghrelin to obtain the $P_{\mathrm{o}} / P_{\text {omax }}$ versus voltage plot shown in Fig. $5 \mathrm{~d}$. We found that both curves were equal. Thus, ghrelin does not change the $P_{\mathrm{o}} / P_{\text {omax }}$ component of the current, although we cannot exclude an effect on the $P_{\text {omax }}$ with our experimental approach. Our data suggest that ghrelin modifies the voltage activation of $\mathrm{Ca}_{\mathrm{v}} 3.3$ and decreases the $N$ and/or $g$ value, which can be interpreted as lower current amplitude without changes in the open probability voltage dependency.

We next investigated the kinetic features of the ghrelinmediated inhibition of $\mathrm{Ca}_{\mathrm{v}} 3.3$. Because $\mathrm{Ca}_{\mathrm{v}} 3.3$ current inhibition by ghrelin persisted during the inactivation phase (Fig. 2), we decided to monitor the inhibition along a 200$\mathrm{ms}$ pulse at $-30 \mathrm{mV}$. Figure 7 displays a representative experiment and the average percentage of inhibition calculated for the charge moved over 16 consecutive intervals of $12.5 \mathrm{~ms}$. We found significant inhibition after the maximum current point persisting throughout the inactivation phase, while no significant inhibition in the first interval. One putative explanation of this observation is a mechanism involving changes in activation and/or inactivation kinetics. We therefore explored if ghrelin modifies the $\mathrm{Ca}_{\mathrm{V}} 3.3$ kinetic parameters. 
a
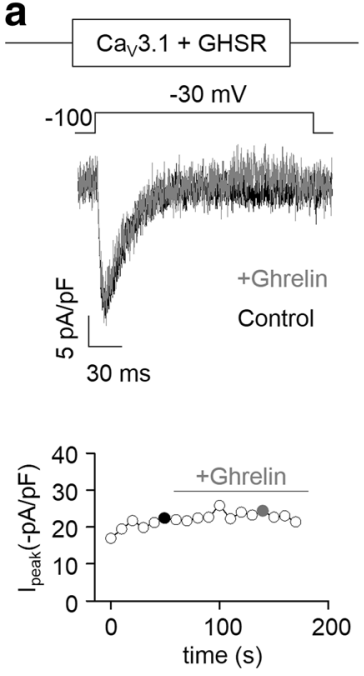

b
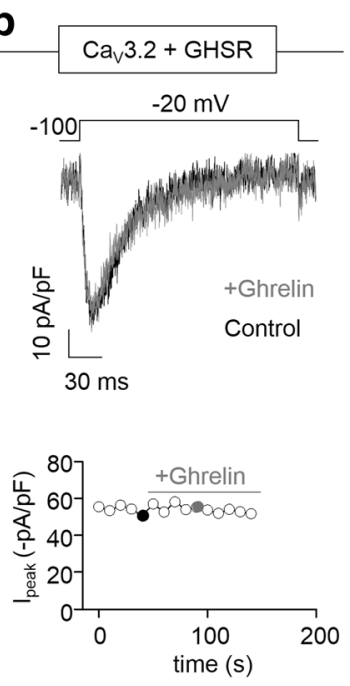

Fig. 3 Ghrelin inhibits $\mathrm{Ca}_{\mathrm{V}} 3.3$ current but not $\mathrm{Ca}_{\mathrm{V}} 3.1$ and $\mathrm{Ca}_{\mathrm{V}} 3.2$ currents. a-c Representative calcium current traces and time course from tsA201 cells transfected with GHSR and either $\mathrm{Ca}_{\mathrm{V}} 3.1$ (a), $\mathrm{Ca}_{\mathrm{V}} 3.2$ (b), or $\mathrm{Ca}_{\mathrm{V}} 3.3$ (c) evoked at $-30 \mathrm{mV}$ or $-20 \mathrm{mV}$ from a holding potential of $-100 \mathrm{mV}$ for $200 \mathrm{~ms}$ in control condition and with

Indeed, we found that both the activation and inactivation time constants (tau) decrease in the presence of ghrelin at several voltages (Fig. 8a, b). Moreover, we completed the kinetic analysis by testing the deactivation kinetic behavior and found that the deactivation time constant remains unchanged in presence of ghrelin (Fig. 8c). Taken together, our data indicate that, besides the reduction in the $G_{\max }$ (Fig. 6d), there is a kinetic component that contributes to the effect of ghrelin on $\mathrm{Ca}_{\mathrm{V}} 3.3$ currents.

How T-currents enter or recover from an inactivated state is critical to its contribution to action potential firing in neurons $[14,54]$. Thus, we evaluated how ghrelin affects these events for $\mathrm{Ca}_{\mathrm{V}} 3.3$. We found that ghrelin has an impact on the

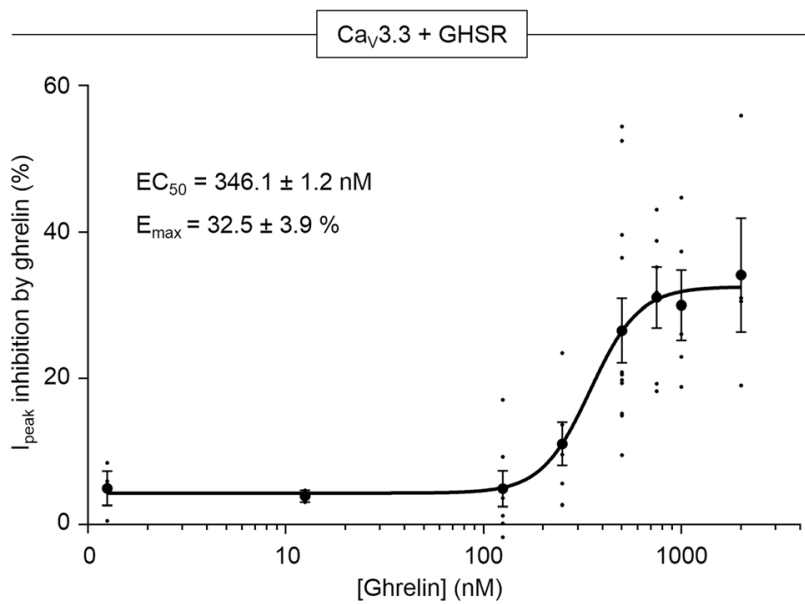

Fig. 4 Ghrelin inhibits $\mathrm{Ca}_{\mathrm{v}} 3.3$ in a concentration-dependent manner. Ghrelin dose-response curve of $\mathrm{Ca}_{\mathrm{V}} 3.3$ current inhibition in tsA201 cells transfected with $\mathrm{Ca}_{\mathrm{V}} 3.3$ and GHSR (Ghrelin concentration range 1.25$2000 \mathrm{nM}$ ). Dots represent individual cell analyzed and line represents the fitted Hill equation $\left(r^{2}=0.54\right)(n=22)$

C
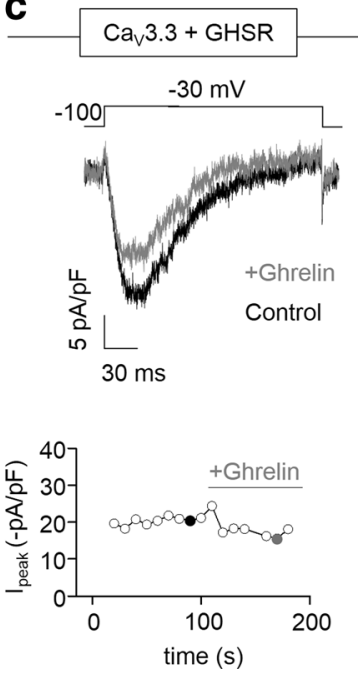

d

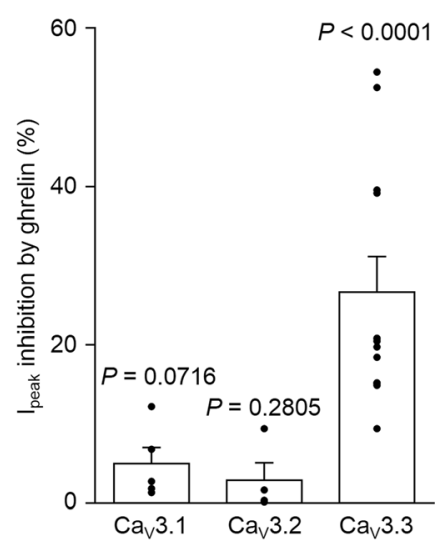

the application of $500 \mathrm{nM}$ ghrelin and averaged percentage of calcium current peak $\left(I_{\text {peak }}\right)$ inhibition by $500 \mathrm{nM}$ ghrelin (d). Dots represent the inhibition calculated for individual cell. $(\mathbf{a}, n=5 ; \mathbf{b}, n=4 ; \mathbf{c}, n=12)$. Onesample Student's $t$ test, test value $=0$

entrance to steady-state inactivation reflected in a shift in the half potential of steady state inactivation $\left(V_{1 / 2}\right)$ to hyperpolarized potentials (Fig. 9a). On the other hand, we failed to observe a difference in the recovery from short time inactivation process (Fig. 8b).

In order to predict the impact of ghrelin-mediated $\mathrm{Ca}_{\mathrm{v}} 3.3$ biophysical changes in neurons, we decide to use simulation software to model action potentials firing. This approach is valuable since the three $\mathrm{T}$-channel subtypes are widely expressed in the brain and there is a lack of specific inhibitors for isolating their currents $[12,55]$. We decided to use the simulation software (NEURON) which allow us to model the effect of ghrelin while changing the contribution of $\mathrm{Ca}_{\mathrm{v}} 3.3$ to the total T-current participating in the action potential firing of thalamic reticular neurons [45]. Although the effect of ghrelin has not been described in this particular brain area, we considered that this model highly used for modeling $\mathrm{T}$ currents contribution to firing is suitable to explore the impact of ghrelin. Beside the T-current, the model includes sodium and potassium conductances. In this context, we have in consideration the inhibition of potassium current by ghrelin previously reported for several neuronal types [11]. We first evaluated the effect of ghrelin on the firing frequency and the latency time to the first action potential by introducing the changes in this conductance as it has been reported. Then, we modeled the effect of ghrelin on T-current parameters corresponding to the $\mathrm{Ca}_{\mathrm{V}} 3.3$ current component inhibited by ghrelin. In other words, we ran the program simulating the effect of ghrelin by changing the parameters included in the Boltzmann equation for steady-state inactivation $\left(h_{\infty}\right)(2)$ and the one phase decay exponential equations for the voltage dependency of the activation $\left(\mathrm{Tau}_{\mathrm{m}}\right)(3)$ and inactivation 


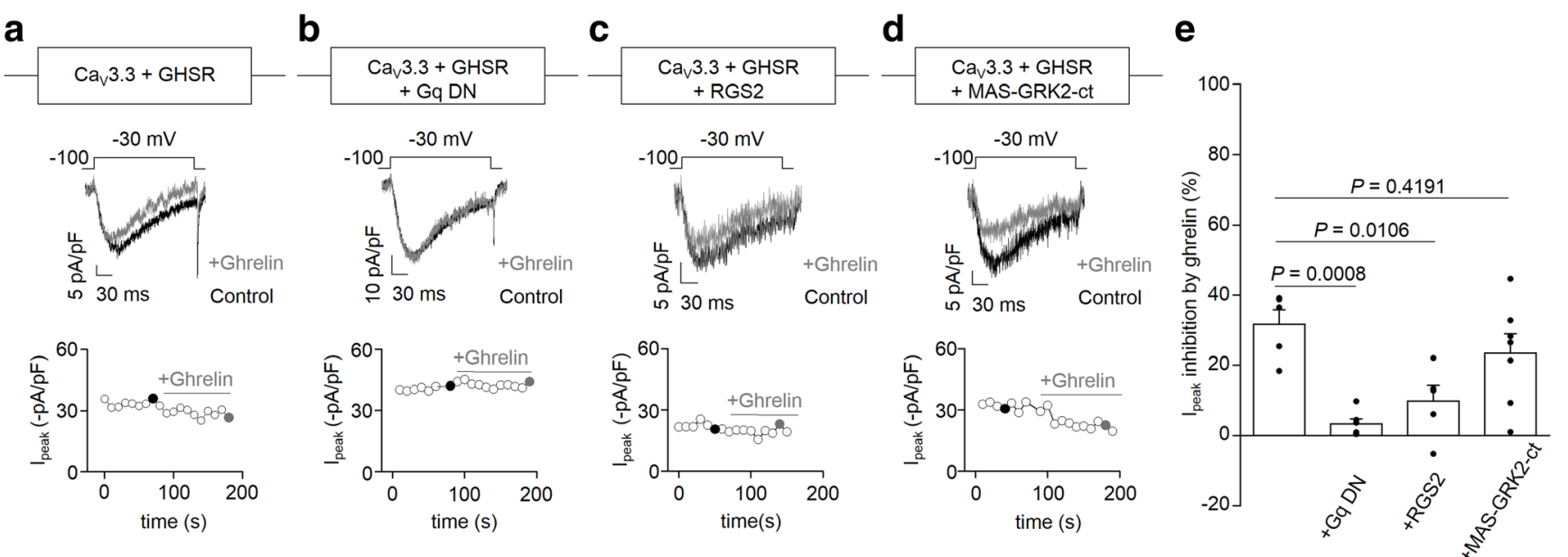

Fig. $5 \mathrm{Ca}_{\mathrm{v}} 3.3$ inhibition by ghrelin is signaled by $\mathrm{G}_{\mathrm{q}}$ protein but not by $\mathrm{G}_{\beta \gamma}$. a-d Representative calcium current traces and time course from tsA201 cells transfected with $\mathrm{Ca}_{\mathrm{v}} 3.3$, GHSR, and either pcDNA3.1 (a), $\mathrm{G}_{\mathrm{q}} \mathrm{DN}$ (b), RGS2 (c), or MAS-GRK2-ct (d) evoked at - $30 \mathrm{mV}$ from a holding potential of $-100 \mathrm{mV}$ for $200 \mathrm{~ms}$ in control condition and with the application of $500 \mathrm{nM}$ ghrelin and averaged percentage of calcium current peak $\left(I_{\text {peak }}\right)$ inhibition by $500 \mathrm{nM}$ ghrelin (e). Dots represent the inhibition calculated for individual cell. $\mathbf{a}, n=5 ; \mathbf{b}, n=6 ; \mathbf{c}, n=5 ; \mathbf{d}, n=$ 7. One way-ANOVA with Dunnett's post-test a

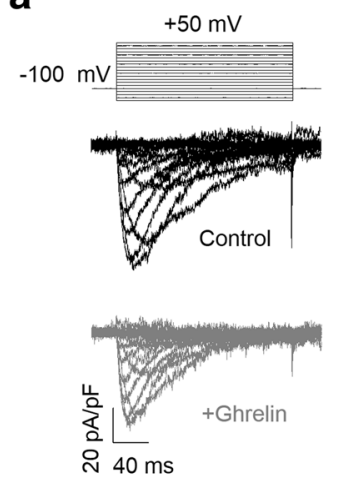

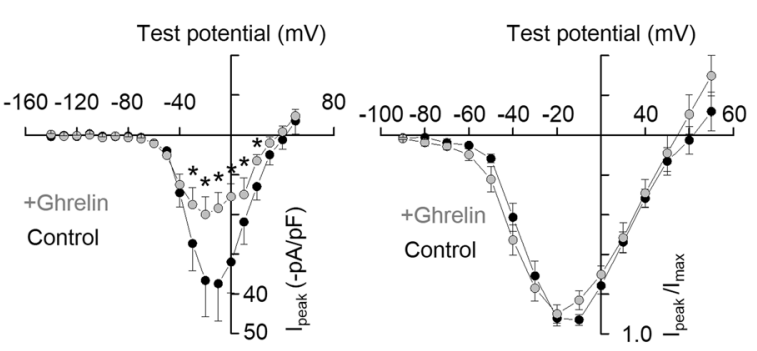

$I_{\mathrm{IV}}(\mathrm{V})=\frac{\left[G_{\max } \times\left(\mathrm{V}-\mathrm{V}_{\text {rev }}\right)\right]}{\left[1+\exp \left(\left(\mathrm{V}_{1 / 2}-\mathrm{V}\right) / \mathrm{k}\right)\right]}=\mathrm{P}_{\mathrm{o}}(\mathrm{V}) \times \mathrm{N} \times \mathrm{g} \times\left(\mathrm{V}-\mathrm{V}_{\text {rev }}\right)$
C

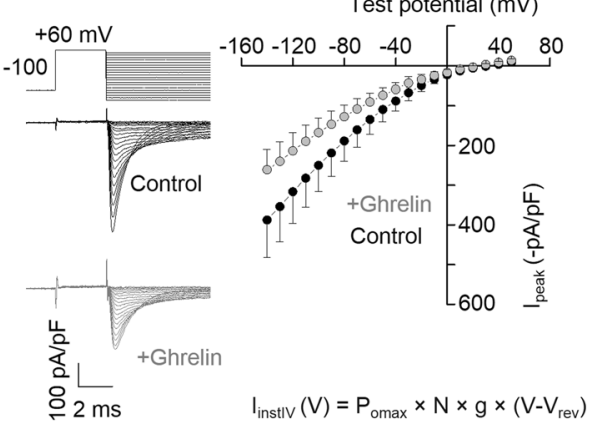

b
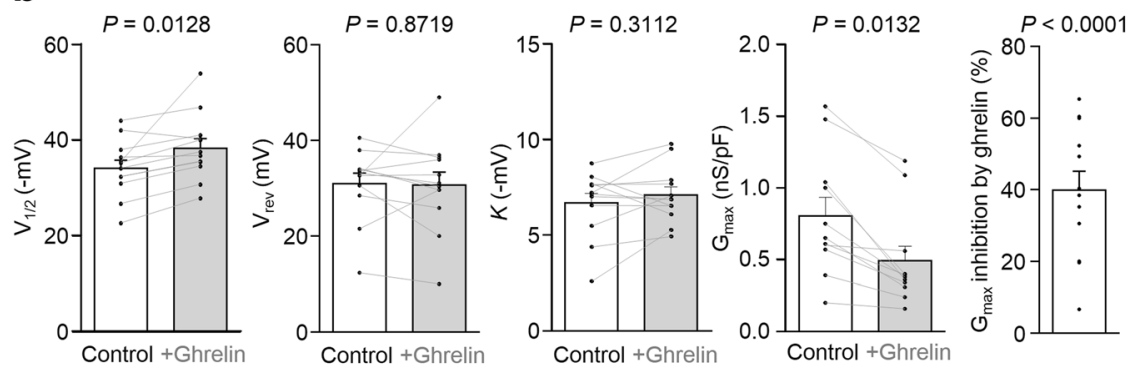

d

Fig. 6 Ghrelin decreases the Cav3.3 maximum conductance without changes in the open probability voltage dependency. a Representative calcium current traces from tsA201 cells transfected with $\mathrm{Ca}_{\mathrm{V}} 3.3$ and GHSR evoked by step depolarizations from a holding potential of $100 \mathrm{mV}$ to varying test potentials of $-140 \mathrm{mV}$ to $+50 \mathrm{mV}$ for $200 \mathrm{~ms}$ in control condition and with the application of $500 \mathrm{nM}$ ghrelin. Averaged calcium current peak-voltage $(I-V)$ relationship (left) and normalized calcium $I-V$ relationship (right). Stars represent statistical differences with $P<0.05(n=12)$. Paired sample Student's $t$ test. Equation describes the Boltzmann linear function and the theoretical $I-V$ relationship. b Bars represent average activation $\left(V_{1 / 2}\right)$ and reversal $\left(V_{\text {rev }}\right)$ potential, $K$, and $G_{\max }$ values obtained in control conditions and with the application of $500 \mathrm{nM}$ ghrelin. Dots and lines represent individual cells $(n=12)$. Paired sample Student's $t$ test. Right bar represents averaged percentage of $G_{\max }$ inhibition by $500 \mathrm{nM}$ ghrelin, and dots represent the inhibition calculated for individual cells. One-sample Student's $t$ test, test value $=0$. c Representative tail calcium current traces from tsA201 cells transfected with $\mathrm{Ca}_{\mathrm{V}} 3.3$ and GHSR evoked by pre-pulse at $+60 \mathrm{mV}$ to varying repolarization potentials from a holding potential of $-100 \mathrm{mV}$ in control condition and with the application of $500 \mathrm{nM}$ ghrelin and averaged values (instant $I-V$ relationship, $n=5$ ). Equation describes the theoretical instantaneous $I-V$ curve. d Averaged $P_{\mathrm{o}} / P_{\text {omax }}$ versus voltage relationship. Line represents the fitted Boltzmann function in a control condition and with the application of $500 \mathrm{nM}$ of ghrelin $(n=5)$. Extra sum-of-square $F$ test. $F=0.5859(\mathrm{DFn}=4, \mathrm{DFd}=211), P=0.6717$ 
a

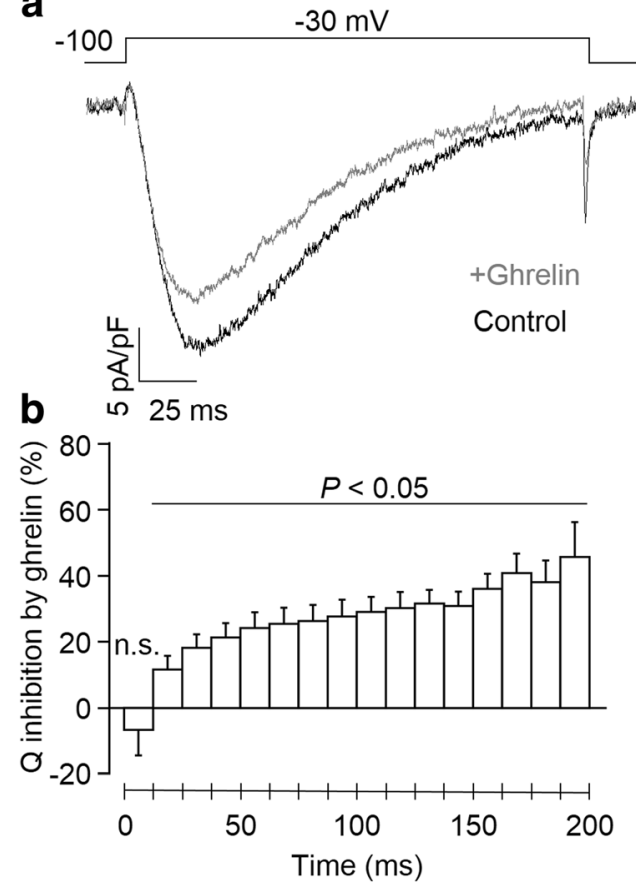

Fig. $7 \mathrm{Ca}_{\mathrm{V}} 3.3$ inhibition by ghrelin persists during the inactivation phase. a Representative calcium current traces from transfected tsA201 cells with $\mathrm{Ca}_{\mathrm{V}} 3.3$ and GHSR evoked at $-30 \mathrm{mV}$ from a holding potential of $-100 \mathrm{mV}$ for $200 \mathrm{~ms}$ in control condition and with the application of $500 \mathrm{nM}$ ghrelin. b Bars represent averaged percentage of calcium current charge $(Q)$ inhibition by ghrelin calculated over 16 consecutive intervals of $12.5 \mathrm{~ms}(n=9)$. One-sample Student's $t$ test, test value $=0$

$\left(\mathrm{Tau}_{\mathrm{h}}\right)(4)$ time constants (see methods and Table 1) based on our experimental data in control and in presence of ghrelin. In addition, we used the same parameters for the Boltzmann equation for activation $\left(m_{\infty}\right)$ (1) because ghrelin does not affect this biophysical property of $\mathrm{Ca}_{\mathrm{v}} 3.3$ as we showed in Fig. 6d. We tested different contributions of $\mathrm{Ca}_{\mathrm{v}} 3.3$ to the total T-current (named as $I_{\mathrm{T}}$ in the model) ranging from 0 to $100 \%$. The remaining T-current was completed by adaptation of previously published data for the $\mathrm{Ca}_{\mathrm{v}} 3.1$ and $\mathrm{Ca}_{\mathrm{v}} 3.2$ components in equal amounts (Table 1) [12]. Figure 10A displays the simulated action potential trains outputs and the frequency values obtained. As expected, we found that the reduction of potassium current by ghrelin would increase firing frequency. On the other hand, the effect of ghrelin on $\mathrm{Ca}_{\mathrm{v}} 3.3$ would reduce firing frequency. Interestingly, when we merged the effects of ghrelin on $\mathrm{Ca}_{\mathrm{v}} 3.3$ and the potassium channels, we found a substantial impairment in the increase in firing frequency produced by ghrelin. We also assayed the latency time to the first action potential (Fig. 10b) and found that the effect of ghrelin on $\mathrm{Ca}_{\mathrm{V}} 3.3$ would increase this value in comparison with the control. On the other hand, inhibition of potassium current by ghrelin slightly reduces the latency time, and this reduction is occluded by incorporating the effect on $\mathrm{Ca}_{\mathrm{V}} 3.3$ into the simulation. The firing rate increased by ghrelin is diminished as we increased the contribution of $\mathrm{Ca}_{\mathrm{V}} 3.3$ to the total modeled
T-current. Taken together, our data suggest that increasing the contribution of $\mathrm{Ca}_{\mathrm{V}} 3.3$ to the total T-current could result in a moderation of the increment of neuronal electrical activity by ghrelin.

\section{Discussion}

Our current data show that ghrelin has a selective effect on $\mathrm{Ca}_{\mathrm{V}} 3.3$ channels without altering other $\mathrm{Ca}_{\mathrm{V}} 3$ subtypes. The activation of GHSR by ghrelin has a profound effect on $\mathrm{Ca}_{\mathrm{V}} 3.3$, modifying the $G_{\max }$ of the current with a slight leftshift in the voltage dependency of the activation. Moreover, ghrelin induces faster activation and inactivation kinetics, as well as a hyperpolarizing shift in steady-state inactivation. We also used a neuron model to simulate the impact of this complex effect on ghrelin modulation of neuron firing. We could propose that the effect of ghrelin on $\mathrm{Ca}_{\mathrm{V}} 3.3$ would act as a negative feedback mechanism at high concentrations of ghrelin preventing an excessive increase in firing frequency.

Here, we showed that ghrelin modifies one of the $\mathrm{Ca}_{\mathrm{v}} 3$ that supports T-currents implicated in neuronal excitability. Remarkably, our data are very similar to the previous work from Chemin and collaborators [56] studying the effect of anandamine. This endogenous cannabinoid modifies $\mathrm{Ca}_{\mathrm{v}} 3.3$ biophysical parameters (activation and inactivation kinetics, steady-state inactivation curve, and a small change in the $I-$ $V$ curve) in a similar manner to the effect of ghrelin described here, acting through its specific GPCR. Since anandamine inhibits T-currents independently of $\mathrm{G}$ protein, it is possible to propose that there are some intrinsic features of the $\mathrm{Ca}_{\mathrm{v}} 3.3$ channel that are potentially modified in a conserved manner by different effectors. How does this complex effect impact neuronal firing? It is difficult to directly predict this impact. Moreover, we have to consider that ghrelin also inhibits potassium current, which is responsible for shaping the repolarizing phase of action potentials in numerous neuronal types [11]. It is important to note that the concentration of ghrelin required to inhibit potassium current is one order of magnitude lower than the concentration we found necessary to inhibit the $\mathrm{Ca}_{\mathrm{v}} 3.3$ [11]. Moreover, both concentrations are higher than the $K_{\mathrm{i}}$ value for ghrelin binding to its receptor (around $1.9 \mathrm{nM}$ [57]). In order to combine both effects, we used a simulation model that allowed us to predict the effect of ghrelin on $\mathrm{Ca}_{\mathrm{V}} 3.3$ and potassium current on firing. We found that the effect of ghrelin on $\mathrm{Ca}_{\mathrm{v}} 3.3$ would counteract its effect on potassium current, attenuating the previously reported increase in firing frequency.

We found that $\mathrm{Ca}_{\mathrm{v}} 3.3$ is a target of ghrelin, while $\mathrm{Ca}_{\mathrm{v}} 3.1$ and $\mathrm{Ca}_{\mathrm{v}} 3.2$ are insensitive to the hormone's actions. There are several reports describing modulators that act on specific subtypes of $\mathrm{Ca}_{\mathrm{V}} 3$ [34]. For instance, muscarinic M1 receptor 
a

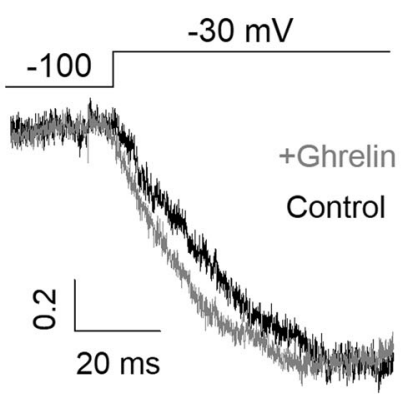

b

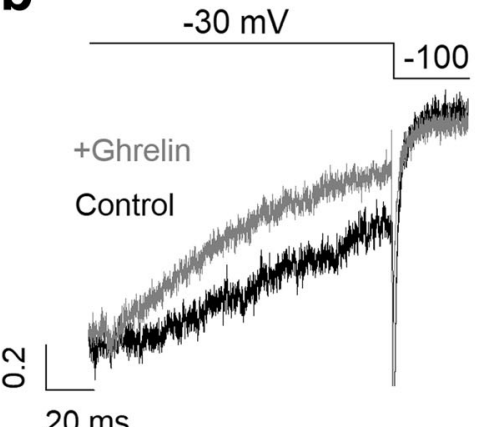

$20 \mathrm{~ms}$

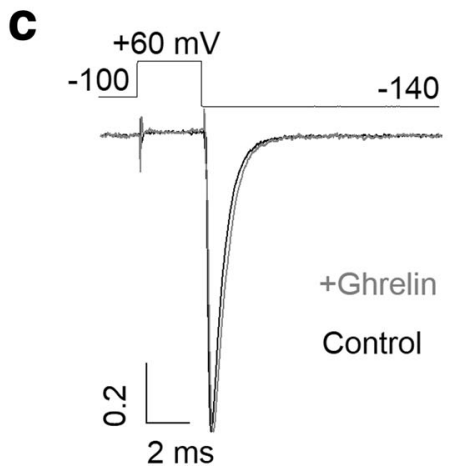

Fig. 8 Ghrelin accelerates $\mathrm{Ca}_{\mathrm{V}} 3.3$ activation and inactivation kinetics, without affecting the deactivation kinetics. a Truncated normalized representative calcium current traces from tsA201 cells transfected with $\mathrm{Ca}_{\mathrm{V}} 3.3$ and GHSR evoked at $-40 \mathrm{mV}$ from a holding potential of $100 \mathrm{mV}$ for $200 \mathrm{~ms}$ in control condition and with the application of $500 \mathrm{nM}$ ghrelin. Average activation tau are plotted as a function of test potentials. Lines represent the fitted single exponential function in each condition $(n=7)$. Extra sum-of-square $F$ test. $F=18.44(\mathrm{DFn}=3, \mathrm{DFd}=$ 90), $P<0.0001$. Paired sample Student's $t$ test for each voltage. b Truncated normalized representative calcium current traces from tsA201 cells transfected with $\mathrm{Ca}_{\mathrm{V}} 3.3$ and GHSR evoked at $-40 \mathrm{mV}$ from a holding potential of $-100 \mathrm{mV}$ for $200 \mathrm{~ms}$ in control condition and with the application of $500 \mathrm{nM}$ ghrelin. Average inactivation tau are plotted as

activation drives $\mathrm{Ca}_{\mathrm{v}} 3.3$ inhibition by $\mathrm{G}_{\mathrm{q} / 11}$ signaling cascade, while $\mathrm{Ca}_{\mathrm{V}} 3.1$ and $\mathrm{Ca}_{\mathrm{V}} 3.2$ are not modified by this mechanism. Besides involving the same $G$ protein, the effect of the M1 receptor is very similar to the effect of ghrelin in terms of the biophysical features of the inhibition [58]. On the other hand, $\mathrm{Ca}_{\mathrm{V}} 3.3$ is insensitive to other GPCR-dependent [59] and -independent [60] cascades that inhibit other $\mathrm{Ca}_{\mathrm{v}} 3$ subtypes. This diversity in the modulation of $\mathrm{Ca}_{\mathrm{V}} 3$ adds complexity to the differential expression pattern of $\mathrm{Ca}_{\mathrm{V}} 3$ subtypes not
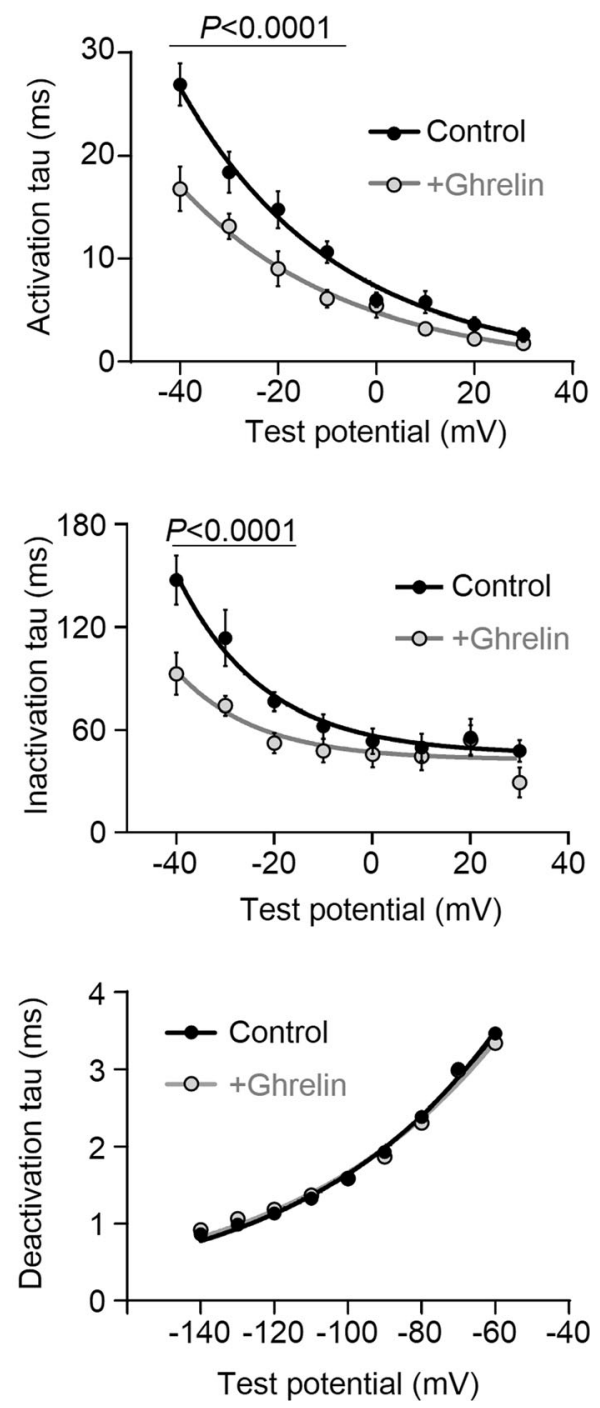

a function of test potentials. Lines represent the fitted single exponential function in each condition $(n=7)$. Extra sum-of-square $F$ test. $\mathrm{F}=10.42$ (DFn $=3, \mathrm{DFd}=69), P<0.0001$. Paired sample Student's $t$ test for each voltage. c Normalized representative calcium tail current traces from tsA201 cells transfected with $\mathrm{Ca}_{\mathrm{V}} 3.3$ and GHSR evoked by pre-pulse at $+60 \mathrm{mV}$ to varying repolarization potentials from a holding potential of $-100 \mathrm{mV}$ in control condition and with the application of $500 \mathrm{nM}$ ghrelin. Average deactivation tau are plotted as a function of repolarization potential. Lines represent the fitted single exponential function in each condition $(n=5)$. Extra sum-of-square $F$ test. $F=0.1107$ (DFn $=2$, $\mathrm{DFd}=86), P=0.8953$. Data points are the average time constants obtained from single exponential fits

only in different brain areas [31] but also throughout developmental stages [61]. Although the absence of direct evidence that $\mathrm{Ca}_{\mathrm{V}} 3.3$ are functionally expressed in hypothalamic neuronal cultures, the fact that this subtype of T channel is highly expressed in the brain during embryonic stages [61] allow us to propose a link between the modulatory effect of ghrelin in embryonic cultures and its specific effect on $\mathrm{Ca}_{\mathrm{v}} 3.3$ currents observed in vitro. Thus, our data and others suggest that modifying the contribution of specific $\mathrm{Ca}_{\mathrm{V}} 3$ subtypes to the $\mathrm{T}$ - 
a

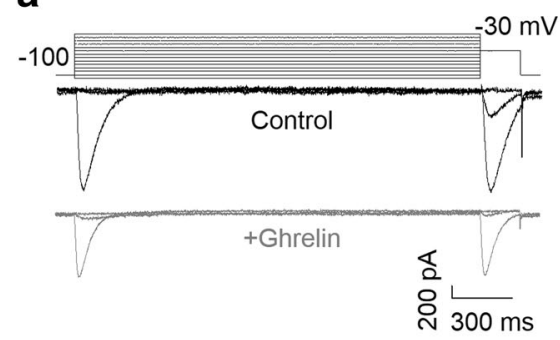

b

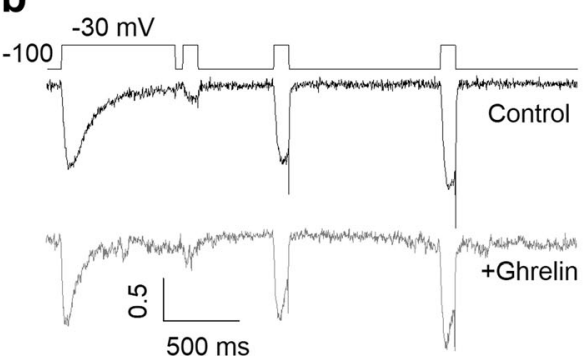

Fig. 9 Ghrelin reduces the $\mathrm{V}_{1 / 2}$ of $\mathrm{Ca}_{\mathrm{V}} 3.3$ steady-state inactivation, but has no impact on $\mathrm{Ca}_{\mathrm{V}} 3.3$ recovery from inactivation. a Representative calcium current traces (left) from tsA201 cells transfected with $\mathrm{Ca}_{\mathrm{V}} 3.3$ and GHSR evoked by step depolarizations to $-30 \mathrm{mV}$ preceded by $2 \mathrm{~s}$ pre-pulse to a potential ranging from -120 to $+20 \mathrm{mV}$ with $10-\mathrm{mV}$ increments from a holding potential of $-100 \mathrm{mV}$ in control condition and with the application of $500 \mathrm{nM}$ ghrelin. Voltage dependence of inactivation and Boltzmann fit for each condition (center) $(n=9)$. Extra sumof-square $F$ test. $F=19.50$ (DFn $=4, \mathrm{DFd}=271), P<0.0001$. Bars (right) represent average inactivation $V_{1 / 2}$ potential in control condition and with ghrelin application. Paired sample Student's $t$ test. b Representative
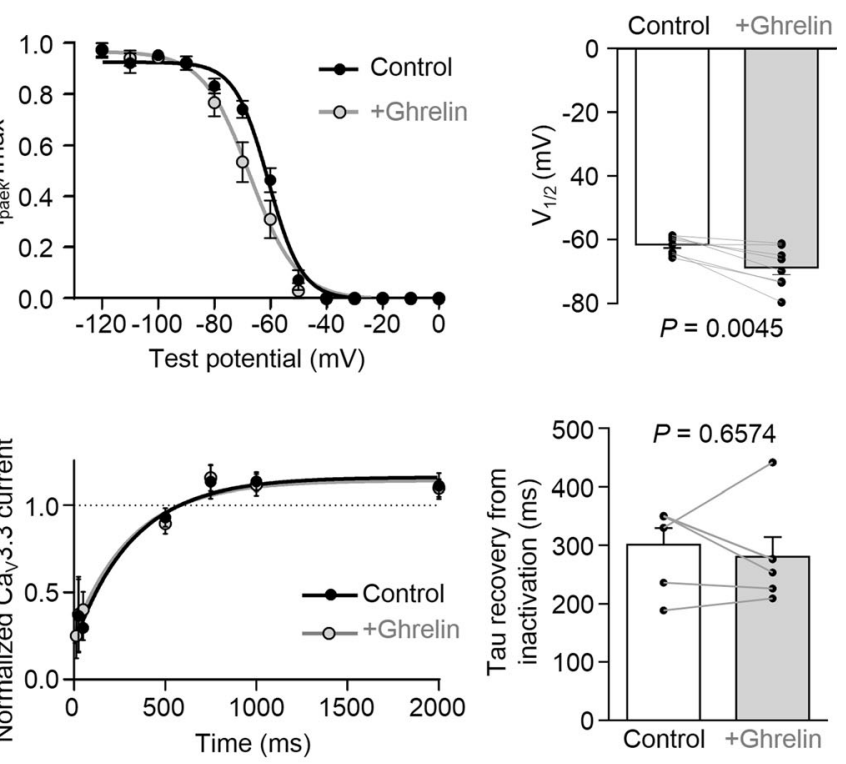

calcium current traces (left) from tsA201 cells transfected with $\mathrm{Ca}_{\mathrm{V}} 3.3$ and GHSR showing how a $500-\mathrm{ms}$ pulse to $-30 \mathrm{mV}$ inactivated calcium currents, which were then allowed to recover at $-100 \mathrm{mV}$ for periods ranging from 12.5 to $2000 \mathrm{~ms}$, then tested during a $30 \mathrm{~ms}$ to $-30 \mathrm{mV}$ in control condition and with the application of $500 \mathrm{nM}$ ghrelin. Dots represent average recovery $\mathrm{Ca}_{\mathrm{V}} 3.3$ current at different periods and lines represent the fitted single exponential function (center) $(n=5)$. Extra sum-of-square $F$ test. $F=16.75(\mathrm{DFn}=3, \mathrm{DFd}=58), P=0.9179$. Bars (right) represent average tau recovery from inactivation in control condition and with ghrelin application. Paired sample Student's $t$ test

GHSR displays two modes of activity, ghrelin-evoked and constitutive, which act via different mechanisms. Ghrelinevoked activity, at the molecular level, is mainly coupled to $\mathrm{G}_{\mathrm{q}}$ and, as a consequence, releases calcium from intracellular stores [62] and activates transcription [7, 8]. At the synaptic
Table 1 Electrophysiological parameters of calcium currents from $\mathrm{Ca}_{\mathrm{v}} 3.1, \mathrm{Ca}_{\mathrm{v}} 3.2, \mathrm{Ca}_{\mathrm{v}} 3.3$, and $\mathrm{Ca}_{\mathrm{V}} 3.3$ plus ghrelin

\begin{tabular}{llllll}
\hline & Parameters & $\mathrm{Ca}_{\mathrm{v}} 3.1$ & $\mathrm{Ca}_{\mathrm{v}} 3.2$ & $\mathrm{Ca}_{\mathrm{v}} 3.3$ & $\mathrm{Ca}_{\mathrm{v}} 3.3+$ ghrelin \\
\hline Activation & $V_{50}(\mathrm{mV})$ & -49.25 & -49.01 & -19.54 & $-19.54 \pm 0.17$ \\
& & \pm 0.17 & \pm 0.22 & \pm 0.17 & \\
& Slope $(\mathrm{mV})$ & $5.17 \pm 0.15$ & $5.45 \pm 0.19$ & $16.43 \pm 2.04$ & $16.43 \pm 2.04$ \\
& $l_{0}$ & $0.00 \pm 0.01$ & $-0.01 \pm 0.01$ & $-0.01 \pm 0.02$ & $-0.01 \pm 0.07$ \\
& $l_{\max }$ & $1.00 \pm 0.01$ & $0.99 \pm 0.01$ & $1.03 \pm 0.07$ & $1.03 \pm 0.07$ \\
& $\mathrm{Tau}_{\{0\}}(\mathrm{mS})$ & $2.21 \pm 0.09$ & $1.44 \pm 0.03$ & $7.28 \pm 0.60$ & $4.80 \pm 0.55$ \\
& $\operatorname{Tau}_{\{-\}}(\mathrm{mS})$ & $2.08 \pm 0.10$ & $1.27 \pm 0.03$ & $0.43 \pm 2.73$ & $0.77 \pm 2.80$ \\
& $k\left(\mathrm{mV}^{\prime 1}\right)$ & $0.08 \pm 0$ & $0.07 \pm 0.00$ & $0.03 \pm 0.01$ & $0.03 \pm 0.01$ \\
& $V_{50}(\mathrm{mV})$ & -74.18 & -75.24 & -60.97 & $-67.51 \pm 102$ \\
& $\mathrm{Slope}(\mathrm{mV})$ & $5.44 \pm 0.17$ & $6.29 \pm 0.27$ & $5.95 \pm 0.46$ & $8.44 \pm 0.89$ \\
& $l_{0}$ & $0.99 \pm 0.01$ & $0.99 \pm 0.01$ & $-0.01 \pm 0.01$ & $-0.01 \pm 0.01$ \\
& $l_{\max }$ & $0.00 \pm 0.01$ & $-0.01 \pm 0.01$ & $0.92 \pm 0.01$ & $0.97 \pm 0.02$ \\
& $\operatorname{Tau}_{\{0\}}(\mathrm{mS})$ & $12.77 \pm 0.34$ & $18.79 \pm 0.11$ & $56.69 \pm 4.10$ & $46.96 \pm 3.26$ \\
& $\operatorname{Tau}_{\{-\}}(\mathrm{mS})$ & $12.34 \pm 0.44$ & $18.62 \pm 0.13$ & $45.69 \pm 8.74$ & $42.42 \pm 6.33$ \\
& $k\left(\mathrm{mV}^{\prime 1}\right)$ & $0.07 \pm 0.01$ & $0.09 \pm 0.00$ & $0.06 \pm 0.02$ & $0.06 \pm 0.03$ \\
\hline
\end{tabular}



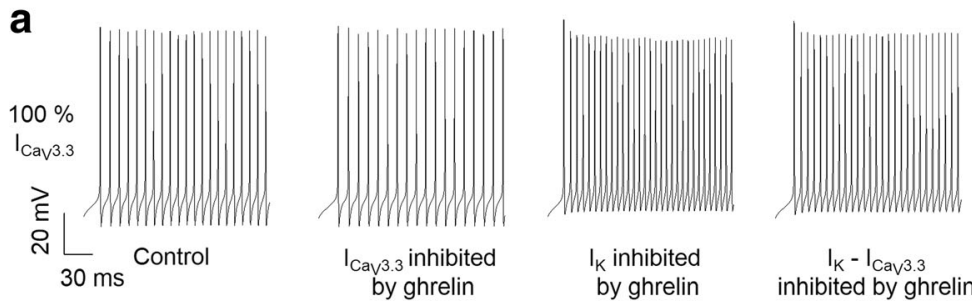

b

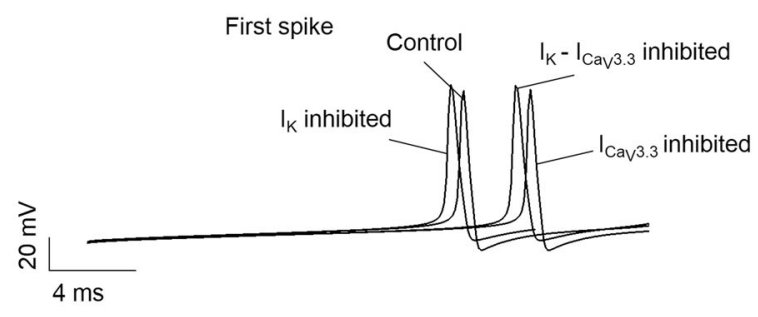

Fig. $10 \mathrm{Ca}_{\mathrm{V}} 3.3$ inhibition by ghrelin modulates firing frequency in neuron simulations. a Simulations of pattern firing in a model of thalamic reticular neuron under four different conditions: control, $\mathrm{Ca}_{\mathrm{V}} 3.3$ current, potassium current, and $\mathrm{Ca}_{\mathrm{V}} 3.3$ current and potassium current inhibited by ghrelin (left). Graphs in the right represent firing

level, ghrelin increases the postsynaptic response to glutamate by stimulating AMPA receptors into the postsynaptic membrane [63]. Both ghrelin-evoked and constitutive activity act on the presynaptic side by inhibiting GABA release. Our laboratory has contributed to understanding this effect produced by constitutive activity, showing that GHSR impairs GABA release by reducing the forward trafficking of $\mathrm{Ca}_{\mathrm{V}} 2$, resulting in lower channel density in the plasma membrane $[9,36]$. Recently, we found that this effect requires $\mathrm{Ca}_{\mathrm{V}} \beta$ subunits and is common for all $\mathrm{Ca}_{\mathrm{V}}$ subtype complexes with $\mathrm{Ca}_{\mathrm{V}} \beta$, including the postsynaptic L-type calcium channels $\left(\mathrm{Ca}_{\mathrm{V}} 1.2\right.$ and $\left.\mathrm{Ca}_{\mathrm{V}} 1.3\right)$ [37]. Thus, our previous work has shown that GHSR constitutive activity modifies the amount of $\mathrm{Ca}_{\mathrm{V}}$ channels at the presynaptic and postsynaptic level, while ghrelinevoked activity acutely impairs presynaptic $\mathrm{Ca}_{\mathrm{V}} 2$ currents affecting GABA release. Here, we present a novel neuronal target of ghrelin-evoked activity: the $\mathrm{Ca}_{\mathrm{V}} 3.3$ that contributes to the T-current shaping action potential firing. In summary, the $\mathrm{Ca}_{\mathrm{v}} 3.3$ is a central target of the ghrelin/GHSR system, which uses a variety of mechanisms to regulate $\mathrm{Ca}_{\mathrm{V}}$ functions and thus control neuronal activity.

Some forms of severe diseases, such as epilepsy and chronic pain, involve T-current anomalies and can be considered channelopathies [64]. These diseases are currently under intense research for new drug development. In this regard, several $\mathrm{Ca}_{\mathrm{V}} 3$ mutants have epileptic phenotypes, and small organic substances that block $\mathrm{Ca}_{\mathrm{V}} 3$ channels are effective in controlling epileptic states [65-67]. Moreover, there is a role described for T-currents in neuropathic pain and T-current blockers have been proposed as part of new therapeutic
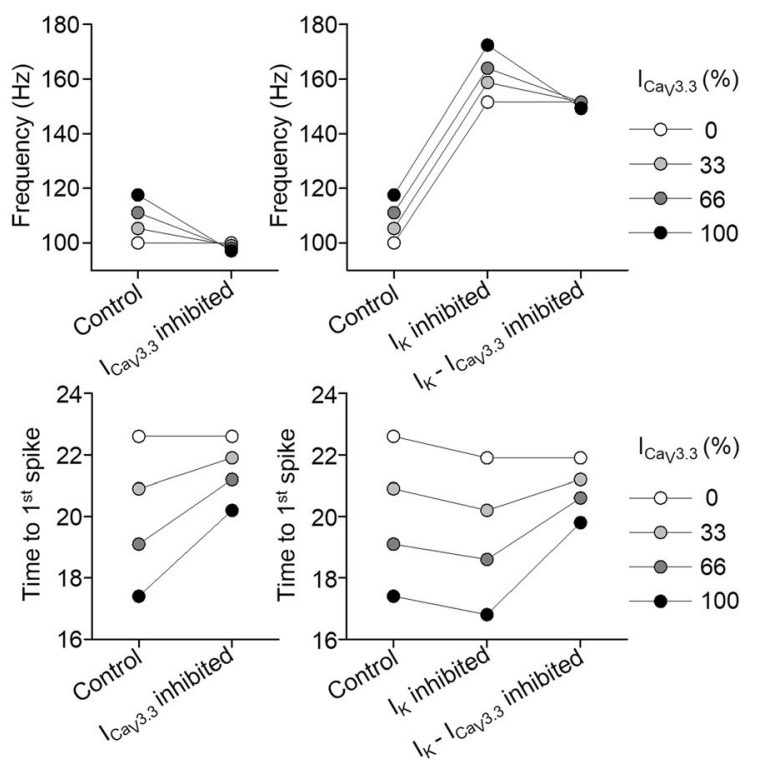

frequency values obtained for each condition at different contributions of $\mathrm{Ca}_{\mathrm{V}} 3.3$ to the total T-current. b Simulated first action potential (left) and graphs (right) representing the latency time to the first action potential values in the same conditions than (a)

strategies for acute, inflammatory, and chronic pain [26]. Meanwhile, since its discovery, ghrelin has been studied as a therapeutic target for several disorders such as obesity and addiction [68]. In particular, many efforts have been focused on ghrelin analogs that could interact with GHSR. In addition to being more stable than ghrelin, these drugs can activate or inhibit specific signaling cascades, or block the receptor's constitutive activity, all with diverse efficacy [57, 69]. Many of these synthetic compounds are available and could be screened as T-current inhibitors, thus contributing to treating pathologies that involve excitation anomalies in the central nervous system. On the other hand, new therapies focused on sequestering ghrelin or reducing its synthesis $[1,70]$ would affect the activity of all ghrelin targets, including $\mathrm{Ca}_{\mathrm{v}} 3.3$. Our data contribute not only to understanding the mechanisms that modulate $\mathrm{Ca}_{\mathrm{v}} 3$ but also to identifying a new target of ghrelin, a neuronal modulator with great pharmacological interest.

Acknowledgments We thank Dr. Veronica Milesi (Instituto de Estudios Inmunológicos y Fisiopatológicos, CONICET-UNLP, La Plata, Argentina) for data discussion and Cambria Chou-Freed for carefully reading our manuscript. We thank Dr. Silvia Rodriguez (Electrophysiology Laboratory) for her excellent technical assistance. This work was supported by the grant of the National Agency of Scientific and Technological Promotion of Argentina (PICT 2015-3330) and by grant of UNLP (X765).

Author Contributions E.R.M. and J.R. designed the experiments; E.R.M. and S.C.G. performed the patch-clamp experiments; E.R.M. analyzed the electrophysiological data; S.C.G and E.R.M. performed modeling experiments; E.R.M. and J.R. prepared the figures; E.R.M. and J.R. wrote the manuscript. All authors reviewed the manuscript. 


\section{Compliance with Ethical Standards}

Conflict of Interest The authors declare that they have no conflict of interest.

\section{References}

1. Nakazato M, Murakami N, Date Y, Kojima M, Matsuo H, Kangawa $\mathrm{K}$, Matsukura S (2001) A role for ghrelin in the central regulation of feeding. Nature 409(6817):194-198. https://doi.org/10.1038/ 35051587

2. Diano S, Farr SA, Benoit SC, McNay EC, da Silva I, Horvath B, Gaskin FS, Nonaka N et al (2006) Ghrelin controls hippocampal spine synapse density and memory performance. Nat Neurosci 9(3):381-388. https://doi.org/10.1038/nn1656

3. Jerlhag E, Egecioglu E, Dickson SL, Andersson M, Svensson L, Engel JA (2006) Ghrelin stimulates locomotor activity and accumbal dopamine-overflow via central cholinergic systems in mice: implications for its involvement in brain reward. Addict Biol 11(1):45-54. https://doi.org/10.1111/j.1369-1600.2006. 00002.X

4. Ge X, Yang H, Bednarek MA, Galon-Tilleman H, Chen P, Chen M, Lichtman JS, Wang Y et al (2018) LEAP2 is an endogenous antagonist of the ghrelin receptor. Cell Metab 27(2):461-469 e466. https://doi.org/10.1016/j.cmet.2017.10.016

5. M'Kadmi C, Cabral A, Barrile F, Giribaldi J, Cantel S, Damian M, Mary S, Denoyelle S et al (2018) N-terminal liver-expressed antimicrobial peptide 2 (LEAP2) region exhibits inverse agonist activity toward the ghrelin receptor. J Med Chem 62:965-973. https:// doi.org/10.1021/acs.jmedchem.8b01644

6. Dickson SL, Luckman SM (1997) Induction of c-fos messenger ribonucleic acid in neuropeptide $\mathrm{Y}$ and growth hormone $(\mathrm{GH})$-releasing factor neurons in the rat arcuate nucleus following systemic injection of the GH secretagogue, GH-releasing peptide-6. Endocrinology 138(2):771-777. https://doi.org/10.1210/endo.138. 2.4907

7. Holst B, Cygankiewicz A, Jensen TH, Ankersen M, Schwartz TW (2003) High constitutive signaling of the ghrelin receptoridentification of a potent inverse agonist. Mol Endocrinol 17(11): 2201-2210. https://doi.org/10.1210/me.2003-0069

8. Holst B, Brandt E, Bach A, Heding A, Schwartz TW (2005) Nonpeptide and peptide growth hormone secretagogues act both as ghrelin receptor agonist and as positive or negative allosteric modulators of ghrelin signaling. Mol Endocrinol 19(9):24002411. https://doi.org/10.1210/me.2005-0059

9. Lopez Soto EJ, Agosti F, Cabral A, Mustafa ER, Damonte VM, Gandini MA, Rodriguez S, Castrogiovanni D et al (2015) Constitutive and ghrelin-dependent GHSR1a activation impairs CaV2.1 and CaV2.2 currents in hypothalamic neurons. J Gen Physiol 146(3):205-219. https://doi.org/10.1085/jgp.201511383

10. Zhang X, van den Pol AN (2016) Hypothalamic arcuate nucleus tyrosine hydroxylase neurons play orexigenic role in energy homeostasis. Nat Neurosci 19(10):1341-1347. https://doi.org/10. 1038/nn.4372

11. Shi L, Bian X, Qu Z, Ma Z, Zhou Y, Wang K, Jiang H, Xie J (2013) Peptide hormone ghrelin enhances neuronal excitability by inhibition of Kv7/KCNQ channels. Nat Commun 4:1435. https://doi.org/ $10.1038 /$ ncomms 2439

12. Chemin J, Monteil A, Perez-Reyes E, Bourinet E, Nargeot J, Lory P (2002) Specific contribution of human T-type calcium channel isotypes (alpha( $1 \mathrm{G})$, alpha $(1 \mathrm{H})$ and alpha(1I)) to neuronal excitability. J Physiol 540(Pt 1):3-14
13. Cain SM, Snutch TP (2010) Contributions of T-type calcium channel isoforms to neuronal firing. Channels 4(6):475-482. https://doi. org/10.4161/chan.4.6.14106

14. Perez-Reyes E (2003) Molecular physiology of low-voltageactivated t-type calcium channels. Physiol Rev 83(1):117-161. https://doi.org/10.1152/physrev.00018.2002

15. Huguenard JR (1996) Low-threshold calcium currents in central nervous system neurons. Annu Rev Physiol 58:329-348. https:// doi.org/10.1146/annurev.ph.58.030196.001553

16. Williams SR, Toth TI, Turner JP, Hughes SW, Crunelli V (1997) The 'window' component of the low threshold Ca2+ current produces input signal amplification and bistability in cat and rat thalamocortical neurones. J Physiol 505(Pt 3):689-705

17. Dreyfus FM, Tscherter A, Errington AC, Renger JJ, Shin HS, Uebele VN, Crunelli V, Lambert RC et al (2010) Selective T-type calcium channel block in thalamic neurons reveals channel redundancy and physiological impact of I(T)window. J Neurosci 30(1): 99-109. https://doi.org/10.1523/JNEUROSCI.4305-09.2010

18. Thompson SM, Wong RK (1991) Development of calcium current subtypes in isolated rat hippocampal pyramidal cells. J Physiol 439: 671-689

19. Christie BR, Eliot LS, Ito K, Miyakawa H, Johnston D (1995) Different $\mathrm{Ca} 2+$ channels in soma and dendrites of hippocampal pyramidal neurons mediate spike-induced $\mathrm{Ca} 2+$ influx. J Neurophysiol 73(6):2553-2557. https://doi.org/10.1152/jn.1995. 73.6.2553

20. Egger V, Svoboda K, Mainen ZF (2005) Dendrodendritic synaptic signals in olfactory bulb granule cells: local spine boost and global low-threshold spike. J Neurosci 25(14):3521-3530. https://doi.org/ 10.1523/JNEUROSCI.4746-04.2005

21. Egger V, Svoboda K, Mainen ZF (2003) Mechanisms of lateral inhibition in the olfactory bulb: efficiency and modulation of spike-evoked calcium influx into granule cells. J Neurosci 23(20): 7551-7558

22. Lory P, Bidaud I, Chemin J (2006) T-type calcium channels in differentiation and proliferation. Cell Calcium 40(2):135-146. https://doi.org/10.1016/j.ceca.2006.04.017

23. Perez-Reyes E, Cribbs LL, Daud A, Lacerda AE, Barclay J, Williamson MP, Fox M, Rees M et al (1998) Molecular characterization of a neuronal low-voltage-activated T-type calcium channel. Nature 391(6670):896-900. https://doi.org/10.1038/36110

24. Cribbs LL, Lee JH, Yang J, Satin J, Zhang Y, Daud A, Barclay J, Williamson MP et al (1998) Cloning and characterization of alpha1H from human heart, a member of the T-type $\mathrm{Ca} 2+$ channel gene family. Circ Res 83(1):103-109

25. Lee JH, Daud AN, Cribbs LL, Lacerda AE, Pereverzev A, Klockner U, Schneider T, Perez-Reyes E (1999) Cloning and expression of a novel member of the low voltage-activated T-type calcium channel family. J Neurosci 19(6):1912-1921

26. Snutch TP, Zamponi GW (2018) Recent advances in the development of T-type calcium channel blockers for pain intervention. Br J Pharmacol 175(12):2375-2383. https://doi.org/10.1111/bph.13906

27. Kopecky BJ, Liang R, Bao J (2014) T-type calcium channel blockers as neuroprotective agents. Pflugers Arch - Eur J Physiol 466(4):757-765. https://doi.org/10.1007/s00424-014-1454-x

28. Klockner U, Lee JH, Cribbs LL, Daud A, Hescheler J, Pereverzev A, Perez-Reyes E, Schneider T (1999) Comparison of the Ca2 + currents induced by expression of three cloned alphal subunits, alpha1G, alpha1H and alpha1I, of low-voltage-activated T-type $\mathrm{Ca} 2+$ channels. Eur J Neurosci 11(12):4171-4178

29. Shcheglovitov A, Kostyuk P, Shuba Y (2007) Selectivity signatures of three isoforms of recombinant T-type $\mathrm{Ca} 2+$ channels. Biochim Biophys Acta 1768(6):1406-1419. https://doi.org/10.1016/j. bbamem.2007.02.017

30. McRory JE, Santi CM, Hamming KS, Mezeyova J, Sutton KG, Baillie DL, Stea A, Snutch TP (2001) Molecular and functional 
characterization of a family of rat brain T-type calcium channels. J Biol Chem 276(6):3999-4011. https://doi.org/10.1074/jbc. M008215200

31. Iftinca MC (2011) Neuronal T-type calcium channels: what's new? Iftinca: T-type channel regulation. J Med Life 4(2):126-138

32. Zigman JM, Jones JE, Lee CE, Saper CB, Elmquist JK (2006) Expression of ghrelin receptor mRNA in the rat and the mouse brain. J Comp Neurol 494(3):528-548. https://doi.org/10.1002/ cne. 20823

33. Perez-Reyes E (2010) G protein-mediated inhibition of Cav3.2 Ttype channels revisited. Mol Pharmacol 77(2):136-138. https://doi. org $/ 10.1124 / \mathrm{mol} .109 .062133$

34. Zhang Y, Jiang X, Snutch TP, Tao J (2013) Modulation of lowvoltage-activated T-type ca(2)(+) channels. Biochim Biophys Acta 1828(7):1550-1559. https://doi.org/10.1016/j.bbamem.2012.08.032

35. Cabral A, Lopez Soto EJ, Epelbaum J, Perello M (2017) Is ghrelin synthesized in the central nervous system? Int J Mol Sci 18(3). https://doi.org/10.3390/ijms18030638

36. Martinez Damonte V, Rodriguez SS, Raingo J (2018) Growth hormone secretagogue receptor constitutive activity impairs voltagegated calcium channel-dependent inhibitory neurotransmission in hippocampal neurons. J Physiol 596(22):5415-5428. https://doi. org/10.1113/JP276256

37. Mustafa ER, Lopez Soto EJ, Martinez Damonte V, Rodriguez SS, Lipscombe D, Raingo J (2017) Constitutive activity of the ghrelin receptor reduces surface expression of voltage-gated $\mathrm{ca}(2+)$ channels in a CaVbeta-dependent manner. J Cell Sci 130(22):39073917. https://doi.org/10.1242/jcs.207886

38. Cabral A, De Francesco PN, Perello M (2015) Brain circuits mediating the orexigenic action of peripheral ghrelin: narrow gates for a vast kingdom. Front Endocrinol 6:44. https://doi.org/10.3389/ fendo.2015.00044

39. Cabral A, Valdivia S, Fernandez G, Reynaldo M, Perello M (2014) Divergent neuronal circuitries underlying acute orexigenic effects of peripheral or central ghrelin: critical role of brain accessibility. J Neuroendocrinol 26(8):542-554. https://doi.org/10.1111/jne.12168

40. Cowley MA, Smith RG, Diano S, Tschop M, Pronchuk N, Grove KL, Strasburger CJ, Bidlingmaier M et al (2003) The distribution and mechanism of action of ghrelin in the CNS demonstrates a novel hypothalamic circuit regulating energy homeostasis. Neuron 37(4):649-661

41. Raingo J, Castiglioni AJ, Lipscombe D (2007) Alternative splicing controls $\mathrm{G}$ protein-dependent inhibition of $\mathrm{N}$-type calcium channels in nociceptors. Nat Neurosci 10(3):285-292. https://doi.org/10. 1038/nn1848

42. Kammermeier PJ, Ikeda SR (1999) Expression of RGS2 alters the coupling of metabotropic glutamate receptor 1a to M-type $\mathrm{K}+$ and N-type Ca2+ channels. Neuron 22(4):819-829

43. Raingo J, Khvotchev M, Liu P, Darios F, Li YC, Ramirez DM, Adachi M, Lemieux P et al (2012) VAMP4 directs synaptic vesicles to a pool that selectively maintains asynchronous neurotransmission. Nat Neurosci 15(5):738-745. https://doi.org/10.1038/nn.3067

44. Hines ML, Carnevale NT (1997) The NEURON simulation environment. Neural Comput 9(6):1179-1209

45. Destexhe A, Contreras D, Steriade M, Sejnowski TJ, Huguenard JR (1996) In vivo, in vitro, and computational analysis of dendritic calcium currents in thalamic reticular neurons. J Neurosci 16(1): $169-185$

46. Muller TH, Misgeld U, Swandulla D (1992) Ionic currents in cultured rat hypothalamic neurones. J Physiol 450:341-362

47. Lee JH, Gomora JC, Cribbs LL, Perez-Reyes E (1999) Nickel block of three cloned T-type calcium channels: low concentrations selectively block alpha1H. Biophys J 77(6):3034-3042. https://doi.org/ 10.1016/S0006-3495(99)77134-1
48. Zamponi GW, Bourinet E, Snutch TP (1996) Nickel block of a family of neuronal calcium channels: subtype- and subunitdependent action at multiple sites. J Membr Biol 151(1):77-90

49. Mlinar B, Enyeart JJ (1993) Block of current through T-type calcium channels by trivalent metal cations and nickel in neural rat and human cells. J Physiol 469:639-652

50. Pantel J, Legendre M, Cabrol S, Hilal L, Hajaji Y, Morisset S, Nivot S, Vie-Luton MP et al (2006) Loss of constitutive activity of the growth hormone secretagogue receptor in familial short stature. J Clin Invest 116(3):760-768. https://doi.org/10.1172/JCI25303

51. Heximer SP, Watson N, Linder ME, Blumer KJ, Hepler JR (1997) RGS2/G0S8 is a selective inhibitor of Gqalpha function. Proc Natl Acad Sci U S A 94(26):14389-14393

52. Roy AA, Lemberg KE, Chidiac P (2003) Recruitment of RGS2 and RGS4 to the plasma membrane by $\mathrm{G}$ proteins and receptors reflects functional interactions. Mol Pharmacol 64(3):587-593. https://doi. org $/ 10.1124 / \mathrm{mol} .64 .3 .587$

53. Roy AA, Baragli A, Bernstein LS, Hepler JR, Hebert TE, Chidiac $P$ (2006) RGS2 interacts with Gs and adenylyl cyclase in living cells. Cell Signal 18(3):336-348. https://doi.org/10.1016/j.cellsig.2005. 05.004

54. Aizenman CD, Linden DJ (1999) Regulation of the rebound depolarization and spontaneous firing patterns of deep nuclear neurons in slices of rat cerebellum. J Neurophysiol 82(4):1697-1709. https://doi.org/10.1152/jn.1999.82.4.1697

55. Huguenard JR (1998) Low-voltage-activated (T-type) calciumchannel genes identified. Trends Neurosci 21(11):451-452

56. Chemin J, Monteil A, Perez-Reyes E, Nargeot J, Lory P (2001) Direct inhibition of T-type calcium channels by the endogenous cannabinoid anandamide. EMBO J 20(24):7033-7040. https://doi. org/10.1093/emboj/20.24.7033

57. M'Kadmi C, Leyris JP, Onfroy L, Gales C, Sauliere A, Gagne D, Damian M, Mary S et al (2015) Agonism, antagonism, and inverse agonism bias at the ghrelin receptor signaling. J Biol Chem 290(45):27021-27039. https://doi.org/10.1074/jbc.M115.659250

58. Hildebrand ME, David LS, Hamid J, Mulatz K, Garcia E, Zamponi GW, Snutch TP (2007) Selective inhibition of Cav3.3 T-type calcium channels by Galphaq/11-coupled muscarinic acetylcholine receptors. J Biol Chem 282(29):21043-21055. https://doi.org/10. 1074/jbc.M611809200

59. You H, Altier C, Zamponi GW (2010) CCR2 receptor ligands inhibit Cav3.2 T-type calcium channels. Mol Pharmacol 77(2):211217. https://doi.org/10.1124/mol.109.059022

60. Zhang Y, Zhang J, Jiang D, Zhang D, Qian Z, Liu C, Tao J (2012) Inhibition of T-type $\mathrm{Ca}(2)(+)$ channels by endostatin attenuates human glioblastoma cell proliferation and migration. $\mathrm{Br} \mathrm{J}$ Pharmacol 166(4):1247-1260. https://doi.org/10.1111/j.1476-5381.2012. 01852.x

61. Yunker AM, Sharp AH, Sundarraj S, Ranganathan V, Copeland TD, McEnery MW (2003) Immunological characterization of Ttype voltage-dependent calcium channel CaV3.1 (alpha 1G) and CaV3.3 (alpha 1I) isoforms reveal differences in their localization, expression, and neural development. Neuroscience 117(2):321-335

62. Howard AD, Feighner SD, Cully DF, Arena JP, Liberator PA, Rosenblum CI, Hamelin M, Hreniuk DL et al (1996) A receptor in pituitary and hypothalamus that functions in growth hormone release. Science 273(5277):974-977

63. Ribeiro LF, Catarino T, Santos SD, Benoist M, van Leeuwen JF, Esteban JA, Carvalho AL (2014) Ghrelin triggers the synaptic incorporation of AMPA receptors in the hippocampus. Proc Natl Acad Sci U S A 111(1):E149-E158. https://doi.org/10.1073/pnas. 1313798111

64. Nelson MT, Todorovic SM, Perez-Reyes E (2006) The role of Ttype calcium channels in epilepsy and pain. Curr Pharm Des 12(18):2189-2197 
65. Heron SE, Khosravani H, Varela D, Bladen C, Williams TC, Newman MR, Scheffer IE, Berkovic SF et al (2007) Extended spectrum of idiopathic generalized epilepsies associated with CACNA1H functional variants. Ann Neurol 62(6):560-568. https://doi.org/10.1002/ana.21169

66. Powell KL, Cain SM, Snutch TP, O'Brien TJ (2014) Low threshold T-type calcium channels as targets for novel epilepsy treatments. Br J Clin Pharmacol 77(5):729-739. https://doi.org/10.1111/bcp. 12205

67. Proft J, Rzhepetskyy Y, Lazniewska J, Zhang FX, Cain SM, Snutch TP, Zamponi GW, Weiss N (2017) The Cacnalh mutation in the GAERS model of absence epilepsy enhances T-type $\mathrm{Ca}(2+)$ currents by altering calnexin-dependent trafficking of Cav3.2 channels. Sci Rep 7(1):11513. https://doi.org/10.1038/s41598-017-11591-5

68. Seim I, El-Salhy M, Hausken T, Gundersen D, Chopin L (2012) Ghrelin and the brain-gut axis as a pharmacological target for appetite control. Curr Pharm Des 18(6):768-775
69. Asakawa A, Inui A, Kaga T, Katsuura G, Fujimiya M, Fujino MA, Kasuga M (2003) Antagonism of ghrelin receptor reduces food intake and body weight gain in mice. Gut 52(7):947-952

70. Helmling S, Maasch C, Eulberg D, Buchner K, Schroder W, Lange C, Vonhoff S, Wlotzka B et al (2004) Inhibition of ghrelin action in vitro and in vivo by an RNA-Spiegelmer. Proc Natl Acad Sci U S A 101(36):13174-13179. https://doi.org/10.1073/pnas. 0404175101

Publisher's Note Springer Nature remains neutral with regard to jurisdictional claims in published maps and institutional affiliations. 